\title{
1,3-Dipolar cycloadditions of organic azides to ester or benzotriazolylcarbonyl activated acetylenic amides
}

\author{
Alan R. Katritzky, ${ }^{\text {a }}$ Yuming Zhang, ${ }^{a}$ Sandeep K. Singh, ${ }^{a}$ and Peter J. Steel ${ }^{b}$ \\ ${ }^{a}$ Center for Heterocyclic Compounds, Department of Chemistry, \\ University of Florida, Gainesville, Florida 32611-7200, USA \\ ${ }^{b}$ Department of Chemistry, University of Canterbury, Christchurch, New Zealand \\ Email:katritzky@,chem.ufl.edu
}

(received 09 Sep 03; accepted 27 Nov 03; published on the web 12 Dec 03)

\begin{abstract}
Reactions of 3-lithiopropiolate $\mathbf{1 0}$ with isocyanates or diisocyanates gave monocarbamoylpropiolates 11a,b and bis-carbamoylpropiolates 12a-d, in 40-76\% yields. 1,3-Dipolar cycloadditions of benzyl azide (1a) and mono-acetylenes 11a,b under thermal conditions gave mono-triazoles 13a,b in 83 and 84\% yields, respectively. The structure of 13a was confirmed by Xray crystallography. Microwave induced cycloadditions of mono-azide 1a with biscarbamoylpropiolates 12a-d furnished the bis-triazoles 14a-d. Similar reactions of 3(azidomethyl)-3-methyloxetane (15) with mono-acetylenes 11a,b or bis-acetylenes 12a,d produced the mono- and bis-triazoles 16a,b and 17a,b, respectively. Reactions of 1,4bis(azidomethyl)benzene (1b) with mono-acetylenes 11a,b gave the azido-triazoles 18a,b and microwave irradiation with simultaneous air-cooling gave bis-triazoles 19a,b. 1,3-Dipolar cycloaddition of benzotriazolylcarbonyl-substituted acetylene $\mathbf{4}$ and benzyl azide (1a) proceeded smoothly under microwave irradiation or thermal conditions to give the corresponding triazole $\mathbf{2 0}$, which on further treatment with a variety of amines gave the $C$-carbamoyl triazoles $\mathbf{2 1 a}-\mathbf{d}$ in $54-91 \%$ yields.
\end{abstract}

Keywords: 1,2,3-Triazoles, bis-triazoles, 1,3-dipolar cycloaddition, regioisomers, microwaves

\section{Introduction}

1,2,3-Triazoles possess therapeutic value, ${ }^{1}$ are synthetic intermediates in the preparation of medicinal compounds, ${ }^{2}$ and find numerous applications in the chemical industry. ${ }^{3}$ Triazoleoligomers have been considered as new, robust binder systems for high-energy explosive and propellant formulations. ${ }^{4}$ The design and synthesis of such compounds is presently in the initial stage of development, but it is already known that structural features such as the length of chains between the triazole cross-links and the substituents on the triazole ring significantly impact the mechanical properties of triazole-oligomers. 
1,3-Dipolar cycloaddition of azides to alkynes is the optimum method for the preparation of 1,2,3-triazoles ${ }^{3 a, 5}$ and copper (I) catalyzed reactions offer good regioselectivity. ${ }^{5 f}$ Cycloadditions are faster with electron-withdrawing substituents on the acetylene moiety, while their presence on the azide has the opposite effect. ${ }^{5 \mathrm{~d}}$ Previously utilized activating substituents on the alkyne include especially alkoxycarbonyl ${ }^{6}$ and other electron-withdrawing groups such as carboxyl, acyl, cyano, aryl, haloalkyl, trimethylsilyl, phenylsulfonyl or phosphonate. ${ }^{7}$ Functionalities on the acetylene play an important role in the kinetics of 1,3-dipolar cycloaddition reactions; for example, while reactions with alkoxycarbonyl substituents are fast and require low reaction temperature, carbamoylacetylenes require high temperatures and reaction times of $24 \mathrm{~h}$ to one week. ${ }^{7 e, 8}$ The low reactivity of acetyleniccarboxamides towards 1,3-dipolar cycloaddition with azides has remained a problem for direct access to important 1,2,3-triazoles with a carbamoyl substituent; the preparation of these compounds has generally involved the use of easily available 1,2,3-triazole esters, ${ }^{1 \mathrm{a}, 9}$-acids or -imines ${ }^{10}$ as intermediates, followed by a functional group transformation to amide.

Synthesis of oligomers with 1,2,3-triazole subunits is an emerging area in macromolecular chemistry: with examples on the preparation of bis-triazoles or triazole-oligomers by the 1,3-dipolar cycloaddition of diacetylenes and diazides, ${ }^{1 \mathrm{a}, \mathrm{b}}$ diacetylenes and monoazides, ${ }^{11 \mathrm{c}}$ diazides and monoacetylenes, ${ }^{11 \mathrm{~d}}$ or tris-acetylenes and diazides. ${ }^{11 \mathrm{e}}$ The reported examples commonly use ester substituents and mostly require long reaction times (1-5 days) and relatively high temperatures (80$\left.100{ }^{\circ} \mathrm{C}\right) .{ }^{11 \mathrm{a}}$

In continuation of an ongoing program in our laboratories to develop strategies for lowtemperature synthesis of 1,2,3-triazoles ${ }^{12}$ and oligo- and poly-triazoles as new high-energy explosive and propellant ingredients, we now report the 1,3-dipolar cycloadditions of organic azides to ester or benzotriazolylcarbonyl activated acetylenic carboxamides, under mild conditions.

\section{Results and Discussion}

Preparation of acetylenic carboxamides and preliminary experiments on triazole formation. A literature search for the preparation of acetylenic carboxamides revealed few reports; (i) reaction between methyl propiolate and an amine (conducted at $-30{ }^{\circ} \mathrm{C}$, for the desired 1,2-addition to predominate over 1,4-addition), ${ }^{13 \mathrm{a}, \mathrm{b}}$ (ii) Ritter reaction between cyanoacetylene and an appropriate carbenium ion generated in the presence of concentrated sulfuric acid, ${ }^{13 \mathrm{c}}$ (iii) reaction of amines with either the $N$-hydroxysuccinimide ester or a mixed anhydride of propiolic acid. ${ }^{13 \mathrm{~d}}$ Methods (i) and (ii) give low to moderate yields or mixtures with products resulting from 1,4-addition, while method (iii) usually affords a 1:1 mixture of the required acetylenic amide with an amide formed from ethyl chloroformate. ${ }^{13 \mathrm{~d}}$

A general and mild procedure for the preparation of primary, secondary and tertiary amides from carboxylic acids via $\mathrm{N}$-acylbenzotriazoles was recently reported by our group, ${ }^{13 \mathrm{e}}$ but this procedure was not previously tested with acetylenic acids. Since few methods for the preparation of acetylenic amides are available in the literature, we explored the $N$-acylbenzotriazole route. Interestingly, reaction of phenylpropiolic acid (2) with 1-(methylsulfonyl)- $1 H$-benzotriazole (3) ${ }^{13 \mathrm{e}}$ furnished the $N$-propioloylbenzotriazole 4 in 50\% yield. Reaction of 4 with morpholine (5) in THF 
at $25{ }^{\circ} \mathrm{C}$ for $12 \mathrm{~h}$ gave the corresponding acetylenic amide 6 in $53 \%$ yield. Under similar conditions, reaction of 4 with 1,4-diaminocyclohexane (7) gave the acetylenic diamide 8 in $65 \%$ yield (Scheme $1)$.

Our objective was to prepare the triazoles under mild conditions. Reactions of acetylenic amides $\mathbf{6 , 8}$ with benzyl azide (1a) were attempted in refluxing acetone for 12 to $24 \mathrm{~h}$ but no triazole formation could be detected by TLC or ${ }^{1} \mathrm{H}$ NMR analyses and the starting materials were recovered (Scheme 1). Literature reports support the need of high temperatures $\left(>100{ }^{\circ} \mathrm{C}\right)$ to effect the $1,3-$ dipolar cycloadditions of acetylenic amides and organic azides. ${ }^{7 e}$

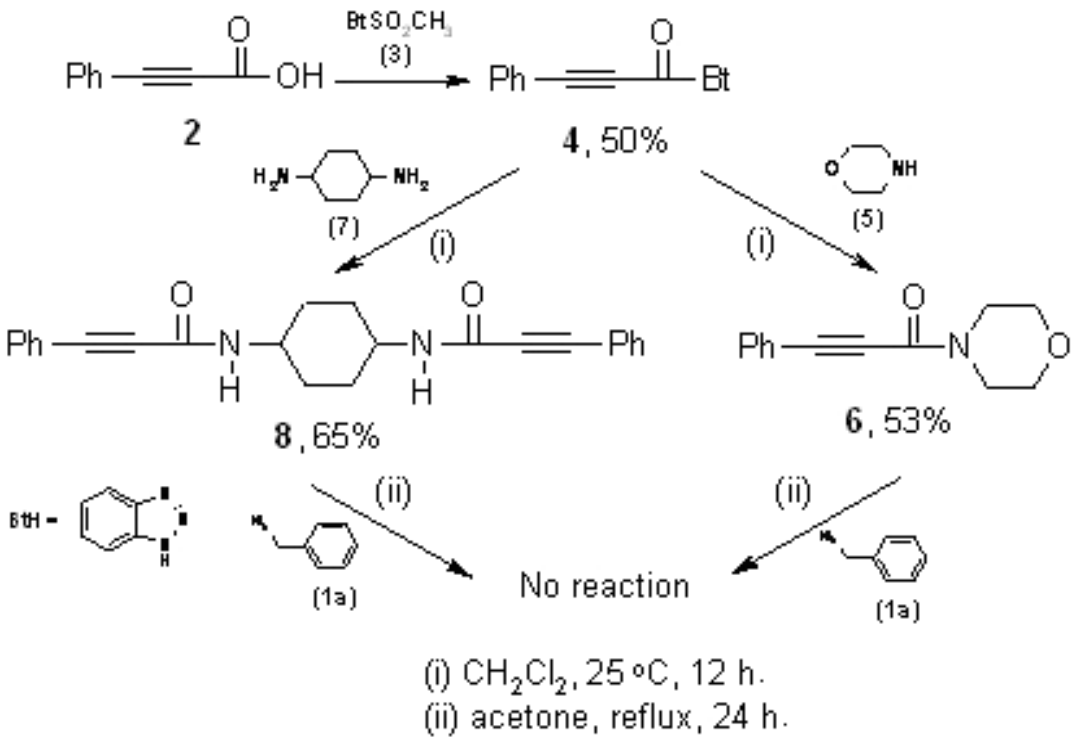

\section{Scheme 1}

The presence of electron-withdrawing substituents on the acetylene facilitates the 1,3-dipolar cycloaddition with organic azides owing to the mechanism and energies of the HOMO-LUMO interactions involved to form the 1,2,3-triazole ring. ${ }^{5 \mathrm{~d}, 14}$ Alkoxycarbonyl has been the most widely used alkyne substituent and 1,3-dipolar cycloadditions of acetylenic esters and organic azides proceed under mild conditions $\left(50-60{ }^{\circ} \mathrm{C}\right)$ to give the corresponding triazoles in good to excellent yields. ${ }^{3 a}$ The failure of 1,3-dipolar cycloaddition of benzyl azide (1a) with acetyleniccarboxamides $\mathbf{6 , 8}$ in refluxing acetone and the requirement of higher reaction temperatures in the reported examples ${ }^{7 \mathrm{e}, 8}$ indicate that the degree of activation provided by the carbamoyl group is much lower than that available from an alkoxycarbonyl substituent. It was concluded that low temperature triazole formation cannot be realized by the presence of the carbamoyl group alone on the acetylene. Therefore, we decided to incorporate an ester group in the acetylenic amides to study their 1,3-dipolar cycloaddition with organic azides under mild conditions.

Preparation of mono- and bis-carbamoylpropiolates. Treatment of ethyl propiolate (9) with $n$ $\mathrm{BuLi}$ at $-78{ }^{\circ} \mathrm{C}$ and reaction of the resulting 3-lithiopropiolate $\mathbf{1 0}$ with phenyl isocyanate or $p$-tolyl isocyanate gave the carboxamido-substituted propiolates 11a and 11b in 76 and $64 \%$ yields, respectively. ${ }^{15}$ Using this procedure, we also prepared bis-carbamoylpropiolates 12a-d. Thus, reaction of the carbanion $\mathbf{1 0}$ with 1,4-phenylene diisocyanate, tolylene 2,4-diisocyanate, 1,6- 
hexamethylene diisocyanate or 4-4'-diphenylmethane diisocyanate furnished the corresponding biscarbamoylpropiolates 12a-d in 40-69\% yields (Scheme 2). Novel bis-carbamoylpropiolates 12a-d were characterized by ${ }^{1} \mathrm{H}$ and ${ }^{13} \mathrm{C}$ NMR spectroscopy and elemental analysis.

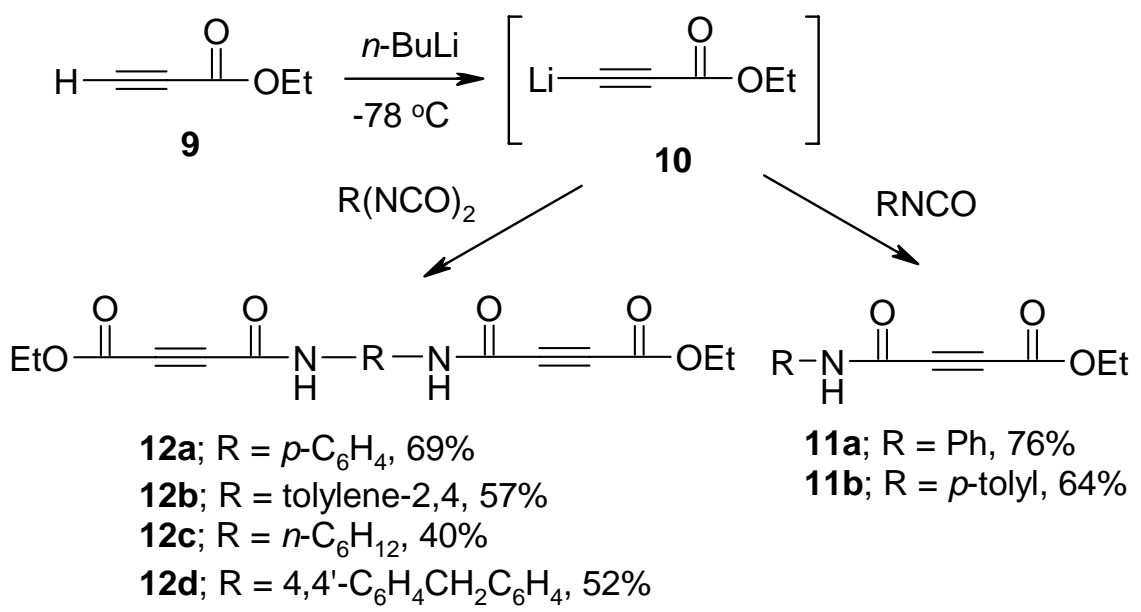

\section{Scheme 2}

Preparation of mono- and bis-triazoles. The concept of increasing the activation of acetylenic amides by further substitution with an ester functionality was realized when 1,3-dipolar cycloadditions of benzyl azide (1a) with carbamoyl-substituted propiolates 11a or 11b proceeded smoothly in refluxing acetone to give the $\mathrm{N}$-substituted 1,2,3-triazoles $\mathbf{1 3} \mathbf{a}$ and $\mathbf{1 3 b}$ as the major regioisomers in 83 and $84 \%$ yields, respectively. The successful preparation of triazoles $\mathbf{1 3 a}, \mathbf{b}$ is the first example of low-temperature 1,3-dipolar cycloaddition of organic azides to ester activated acetylenic amides under thermal conditions (Scheme 3) (Table 1).

Microwave heating has emerged as a useful technique to promote a variety of chemical reactions. ${ }^{16}$ We recently reported our preliminary results on microwave induced 1,3-dipolar cycloadditions of acetylenic carboxamides and organic azides under mild conditions. ${ }^{17}$ Herein, we report the extension of this method to synthesize substituted mono-triazoles by the 1,3-dipolar cycloaddition of mono-azides with mono-acetylenes and bis-triazoles from mono-azides and diacetylenes or di-azides and mono-acetylenes, under microwave irradiation. Thus, microwave reaction of benzyl azide (1a) with bis-carbamoylpropiolate 12a at $100{ }^{\circ} \mathrm{C}$ and $120 \mathrm{~W}$ irradiation power for $1 \mathrm{~h}$ gave a regioisomeric mixture of bis-triazoles. The regioisomers were separated and characterized as bis-triazoles $\mathbf{1 4 a ^ { \prime }}$ and $\mathbf{1 4 a ^ { \prime \prime }}$ in 42 and 37\% yields, respectively. Similar reactions of benzyl azide (1a) with bis-carbamoylpropiolates $12 \mathrm{~b}, \mathbf{1 2 c}$ or $12 \mathrm{~d}$ gave the corresponding bistriazoles $\mathbf{1 4 b}, \mathbf{1 4 c}$ or $\mathbf{1 4 d}$ as the major regioisomers in 41,37 or $73 \%$ yields, respectively (Scheme 3) (Table 1). The corresponding minor isomers were present in the mixtures but were not isolated pure. 


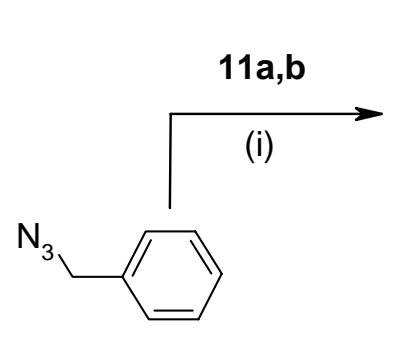<smiles>[R]NC(=O)c1c(C(=O)OCC)nnn1Cc1ccccc1</smiles>

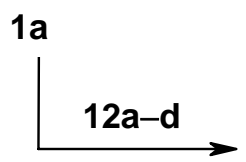

(ii)<smiles>CCOC(=O)c1nnn(Cc2ccccc2)c1C(=O)NNC(=O)c1cn(Cc2ccccc2)nn1</smiles>

$14 a^{\prime}$<smiles>CCOC(=O)c1c(C(=O)NN=C(NC(=O)c2nnn(Cc3ccccc3)c2C(=O)OCC)c2cn(Cc3ccccc3)nn2)nnn1CC</smiles><smiles>CCOC(=O)c1nnn(Cc2ccccc2)c1C(=O)NC(=O)c1c(C(=O)OCC)nnn1Cc1ccccc1</smiles>

$14 b-d$

(i) acetone, reflux, $4 \mathrm{~h}$; (ii) microwaves, $120 \mathrm{~W}, 100^{\circ} \mathrm{C}, 1 \mathrm{~h}$.

Scheme 3. For identity of R, see Table 1.

Under similar conditions, microwave reactions of 3-(azidomethyl)-3-methyloxetane (15) with carbamoylpropiolates $11 \mathrm{a}$ or $11 \mathrm{~b}$ at $55{ }^{\circ} \mathrm{C}$ and $120 \mathrm{~W}$ microwave irradiation power gave the triazoles $\mathbf{1 6 a}$ or $\mathbf{1 6 b}$ as the major regioisomers in 72 and 53\% yields, respectively. Also, the reactions of 15 with bis-carbamoylpropiolates $\mathbf{1 2 a}$ or $\mathbf{1 2 d}$ furnished the bis-triazoles $\mathbf{1 7} \mathbf{a}$ and $\mathbf{1 7 b}$ as the major isomers in 43 and 42\% yields, respectively (Scheme 4) (Table 1). Structures of all the isolated mono- and bis-triazoles were confirmed by $\operatorname{NMR}\left({ }^{1} \mathrm{H}\right.$ and $\left.{ }^{13} \mathrm{C}\right)$ and elemental analysis or high resolution mass spectrometry. 


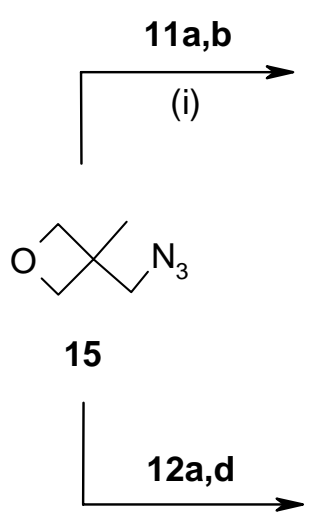

(ii)<smiles>[R]NC(=O)c1c(C(=O)OCC)nnn1CC1(C)COC1</smiles>

$16 a, b$

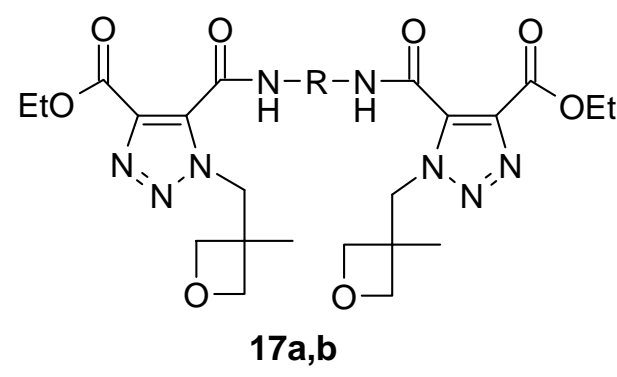

(i) microwaves, $120 \mathrm{~W}, 55^{\circ} \mathrm{C}, 30 \mathrm{~min}$;;(ii) microwaves, $120 \mathrm{~W}$, $100^{\circ} \mathrm{C}, 1 \mathrm{~h}$.

Scheme 4. For identity of R, see Table 1.

Table 1. 1,3-Dipolar Cycloaddition of Organic Azides and Acetylenes to give 1,2,3-Triazoles

\begin{tabular}{ccccc}
\hline Entry & Azide & Acetylene & $\mathrm{R}$ in Triazole & Triazole (\%yield) $^{a}$ \\
\hline 1 & $\mathbf{1 a}$ & $\mathbf{1 1 a}$ & $\mathrm{Ph}$ & $\mathbf{1 3 a}(83)$ \\
2 & $\mathbf{1 a}$ & $\mathbf{1 1 b}$ & $p$-tolyl & $\mathbf{1 3 b}(84)$ \\
3 & $\mathbf{1 a}$ & $\mathbf{1 2 a}$ & $p-\mathrm{C}_{6} \mathrm{H}_{4}$ & $\mathbf{1 4 a ^ { \prime }}(42)$ \\
4 & $\mathbf{1 a}$ & $\mathbf{1 2 a}$ & $p-\mathrm{C}_{6} \mathrm{H}_{4}$ & $\mathbf{1 4 \mathbf { a } ^ { \prime \prime }}(37)$ \\
5 & $\mathbf{1 a}$ & $\mathbf{1 2 b}$ & tolylene- 2,4 & $\mathbf{1 4 b}(41)$ \\
6 & $\mathbf{1 a}$ & $\mathbf{1 2 c}$ & $n-\mathrm{C}_{6} \mathrm{H}_{12}$ & $\mathbf{1 4 c}(37)$ \\
7 & $\mathbf{1 a}$ & $\mathbf{1 2 d}$ & $4,4^{\prime}-\mathrm{C}_{6} \mathrm{H}_{4} \mathrm{CH}_{2} \mathrm{C}_{6} \mathrm{H}_{4}$ & $\mathbf{1 4 d}(73)$ \\
8 & $\mathbf{1 5}$ & $\mathbf{1 1 a}$ & $\mathrm{Ph}$ & $\mathbf{1 6 a}(72)$ \\
9 & $\mathbf{1 5}$ & $\mathbf{1 1 b}$ & $p-$ tolyl & $\mathbf{1 6 b}(53)$ \\
10 & $\mathbf{1 5}$ & $\mathbf{1 2 a}$ & $p-\mathrm{C}_{6} \mathrm{H}_{4}$ & $\mathbf{1 7} \mathbf{a}(43)$ \\
11 & $\mathbf{1 5}$ & $\mathbf{1 2 d}$ & $4,4^{\prime}-\mathrm{C}_{6} \mathrm{H}_{4} \mathrm{CH} \mathrm{H}_{2} \mathrm{C}_{6} \mathrm{H}_{4}$ & $\mathbf{1 7 b}(42)$ \\
12 & $\mathbf{1 b}$ & $\mathbf{1 1 a}$ & $\mathrm{Ph}$ & $\mathbf{1 8 a}(60)$ \\
13 & $\mathbf{1 b}$ & $\mathbf{1 1 a}$ & $\mathrm{Ph}$ & $\mathbf{1 8 a}(12)$ \\
14 & $\mathbf{1 b}$ & $\mathbf{1 1 b}$ & $p$-tolyl & $\mathbf{1 8 b}(54)$ \\
15 & $\mathbf{1 b}$ & $\mathbf{1 1 b}$ & $p$-tolyl & $\mathbf{1 8 b}(18)$ \\
16 & $\mathbf{1 b}$ & $\mathbf{1 1 a}$ & $\mathrm{Ph}$ & $\mathbf{1 9 a}(54)$ \\
17 & $\mathbf{1 b}$ & $\mathbf{1 1 b}$ & $p$-tolyl & $\mathbf{1 9 b}(65)$ \\
\hline
\end{tabular}

${ }^{a}$ Isolated yields.

Next, we explored the preparation of bis-triazoles by 1,3-dipolar cycloadditions of di-azides and mono-acetylenes. Microwave reactions of di-azide 1b with carbamoylpropiolates 11a or 11b at 120 
W irradiation power and $55{ }^{\circ} \mathrm{C}$ temperature for $30 \mathrm{~min}$. resulted in 1,3-dipolar cycloaddition at only one of the azido moieties to give the regioisomeric mixtures of azido-triazoles that were isolated as 18a and 18 $\mathbf{a}^{\prime}$ in 60 and $12 \%$ yields or $\mathbf{1 8 b}$ and $\mathbf{1 8} \mathbf{b}^{\prime}$ in 54 and $18 \%$ yields, respectively (Scheme 5) (Table 1). Triazole formation at the second azido moiety in di-azide $\mathbf{1 b}$ could not be induced even after repeated trials with different reaction conditions. Increasing the temperature or irradiation power to higher levels resulted in charring and decomposition. Interestingly, use of a new model microwave synthesizer equipped with simultaneous irradiation and external air-cooling system proved beneficial. The reaction of 1,4-bis(azidomethyl)benzene (1b) with 2 equiv of ethyl 4anilino-4-oxo-2-butynoate (11a) in toluene under continuous microwave irradiation $(120 \mathrm{~W})$ with simultaneous cooling at $75^{\circ} \mathrm{C}$ for $1 \mathrm{~h}$ furnished a mixture of regioisomeric bis-triazoles; the major regioisomer 19a was isolated by column chromatography in pure form in $54 \%$ yield. Similarly, bistriazole 19b was isolated in $65 \%$ yield from the reaction of di-azide $\mathbf{1 b}$ and ethyl 4-oxo-4-(4toluidino)-2-butynoate (11b) by the simultaneous cooling and irradiation procedure (Scheme 5) (Table 1). Thus, using microwave irradiation we have developed new methods of preparation of substituted bis-triazoles by the 1,3-dipolar cycloadditions of mono-azides and bis-acetylenes or diazides and mono-acetylenes.

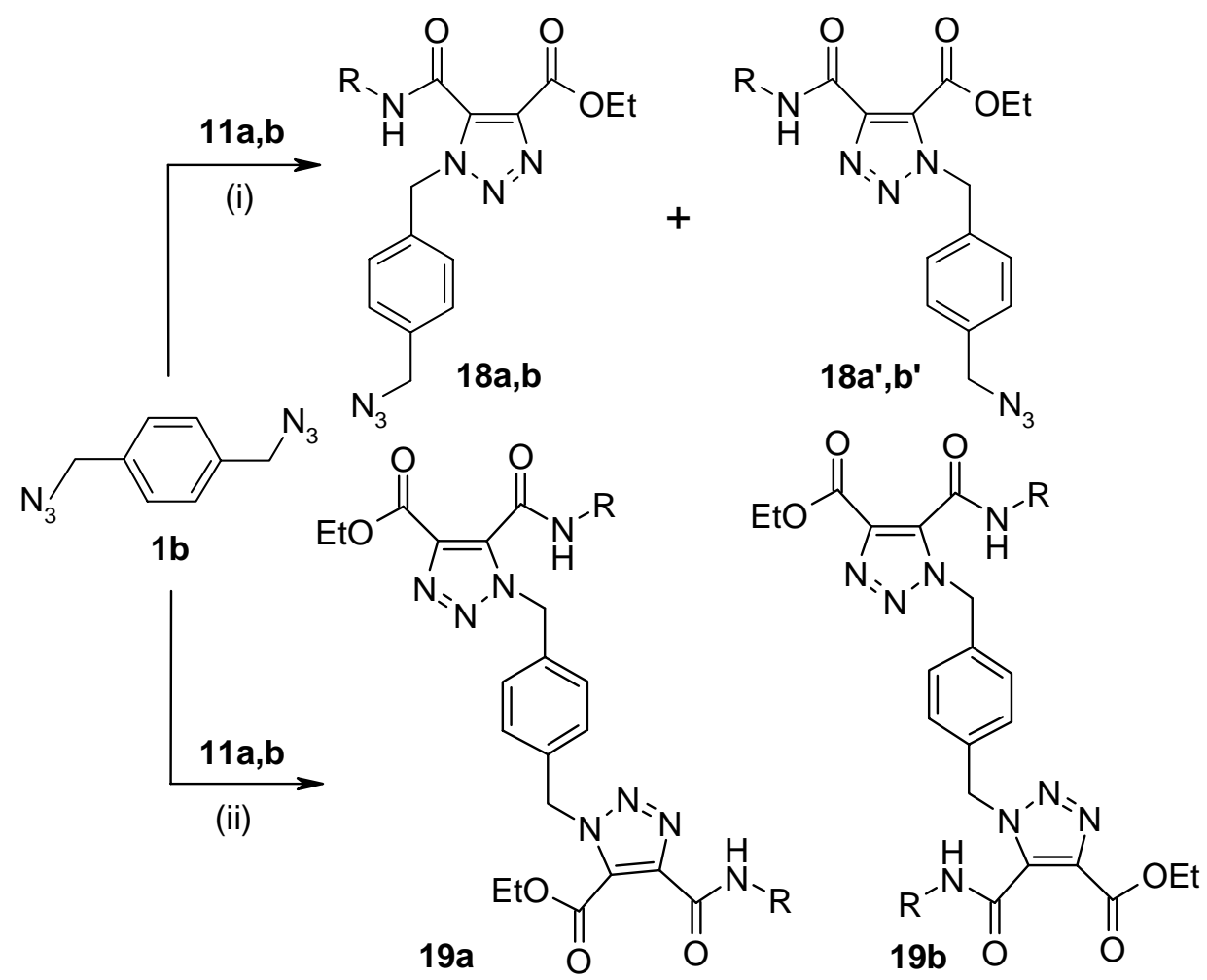

(i) microwaves, $120 \mathrm{~W}, 55^{\circ} \mathrm{C}, 30 \mathrm{~min}$.; (ii) toluene, microwaves, $120 \mathrm{~W}, 75^{\circ} \mathrm{C}$, external cooling, $1 \mathrm{~h}$.

Scheme 5. For identity of R, see Table 1 .

The structure of 13a was confirmed by X-ray crystallography (Figure 1), which unambiguously showed that this is the 5-(phenylcarbamoyl) regioisomer. In the solid state the ester and amide 
groups are approximately coplanar with the triazole ring [angles between meanplanes $=7.7(2)$ and 10.5(2) ${ }^{\circ}$, respectively] and are held in place by an intramolecular hydrogen bond between the amide hydrogen and the ester carbonyl oxygen $\left[\mathrm{H}^{\cdots} \mathrm{O}=1.85(2) \AA, \mathrm{N}^{\cdots} \mathrm{O}=2.742(2) \AA, \mathrm{N}-\mathrm{H}^{\cdots} \mathrm{O}=\right.$ $\left.168(2)^{\circ}\right]$. In contrast the plane of the phenyl ring of the benzyl substituent is approximately orthogonal to the triazole ring [79.1(2) $\left.{ }^{\circ}\right]$. The benzylic protons adjacent to $\mathrm{N}-1$ of the triazole ring in regioisomer 13a resonate at $6.2 \mathrm{ppm}$ as a singlet. ${ }^{1} \mathrm{H}$ NMR spectra of regioisomers $\mathbf{1 3 b}, \mathbf{1 8 a}$ and $\mathbf{1 8 b}$ also display the benzylic protons as singlets at $6.2 \mathrm{ppm}$ and $\mathbf{1 3 b}, \mathbf{1 8 a}$ and $\mathbf{1 8 b}$ were therefore assigned the 5-(phenylcarbamoyl) structures. In the ${ }^{1} \mathrm{H}$ NMR spectra of azido-triazoles $\mathbf{1 8 \mathbf { a } ^ { \prime }}$ and $\mathbf{1 8 b}^{\prime}$, the benzylic proton singlet resonated at $5.8 \mathrm{ppm}$ and regioisomers $\mathbf{1 8 \mathbf { a } ^ { \prime }}$ and $\mathbf{1 8 b}^{\prime}$ were assigned the 4-(phenylcarbamoyl) structure. Two separate singlets at 6.2 and 5.8 ppm for benzylic protons in the bis-triazoles $14 \mathbf{a}^{\prime}$ and 19a suggest the unsymmetrical structures displayed with one triazole ring having a 5-(phenylcarbamoyl) and the other a 4-(phenylcarbamoyl) substituent. Similarly, a singlet at $6.2 \mathrm{ppm}$ for four benzylic protons indicated a symmetrical structure with both the triazole rings having a 5-(phenylcarbamoyl) substituent in bis-triazoles 14b, 14c, 14d and $19 b$. The methylene protons adjacent to $\mathrm{N}-1$ of the triazole ring in $16 \mathbf{a}$ and $\mathbf{1 6 b}$ resonated at $5.2 \mathrm{ppm}$ as a singlet and these regioisomers were assigned the 5-(phenylcarbamoyl) structure. Similarly, a singlet for four methylene protons at $5.2 \mathrm{ppm}$ in bis-triazoles $\mathbf{1 7 a}$ and $\mathbf{1 7 b}$ suggested a symmetrical 5(phenylcarbamoyl) structure.

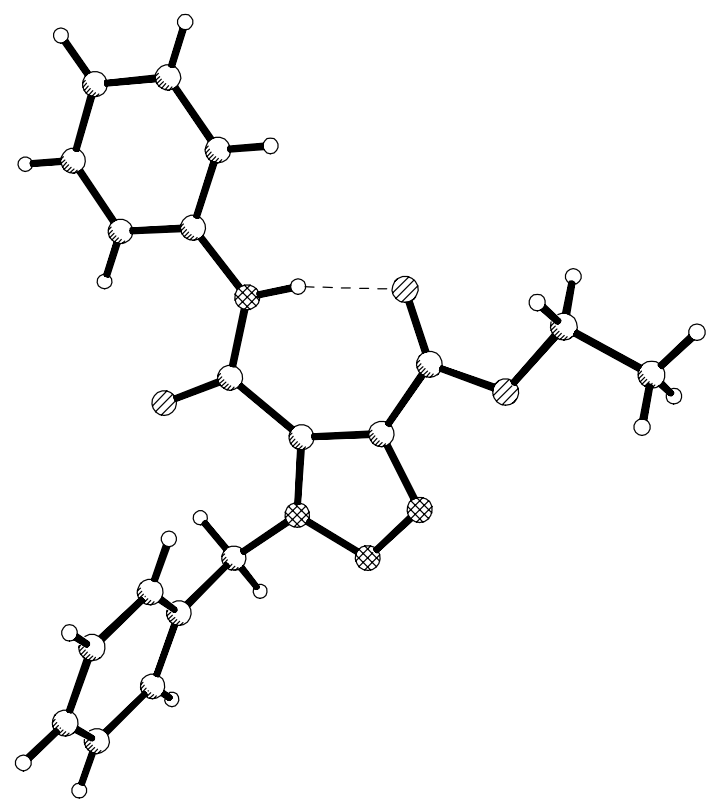

Figure 1. X-ray structure of 13a.

1,3-Dipolar cycloaddition of benzotriazolylcarbonyl activated acetylenes and organic azides. The benzotriazolyl group has been used as a synthetic auxiliary in many chemical transformations. ${ }^{18}$ It was of interest to see whether the presence of a benzotriazolylcarbonyl group on the acetylene 
provides the required activation for 1,3-dipolar cycloaddition with an organic azide. Indeed, the thermal reaction of benzyl azide (1a) with $N$-propioloylbenzotriazole 4 in refluxing acetone for $18 \mathrm{~h}$ gave the benzotriazolylcarbonyl substituted 1,2,3-triazole $\mathbf{2 0}$ in $32 \%$ yield. Alternatively, the microwave reaction of benzyl azide (1a) with 4 at $120 \mathrm{~W}$ and $100{ }^{\circ} \mathrm{C}$ for $1 \mathrm{~h}$ provided 20 in an improved yield of $75 \%$. Further treatment of $\mathbf{2 0}$ with amines ${ }^{13 \mathrm{e}}$ such as morpholine, $p$-chloroaniline, phenethylamine or benzylamine in dichloromethane at $25^{\circ} \mathrm{C}$ for $12 \mathrm{~h}$ replaced the benzotriazolyl group to give the corresponding $C$-carbamoyl 1,2,3-triazoles 21a-d in $54-91 \%$ yields. This strategy demonstrates the utility of benzotriazolylcarbonyl group as an activating group for 1,3-dipolar cycloaddition of azides with alkynes and subsequent displacement of the benzotriazolyl group by the amine moiety to form the corresponding $C$-carbamoyl triazoles under mild conditions (Scheme $6)$.

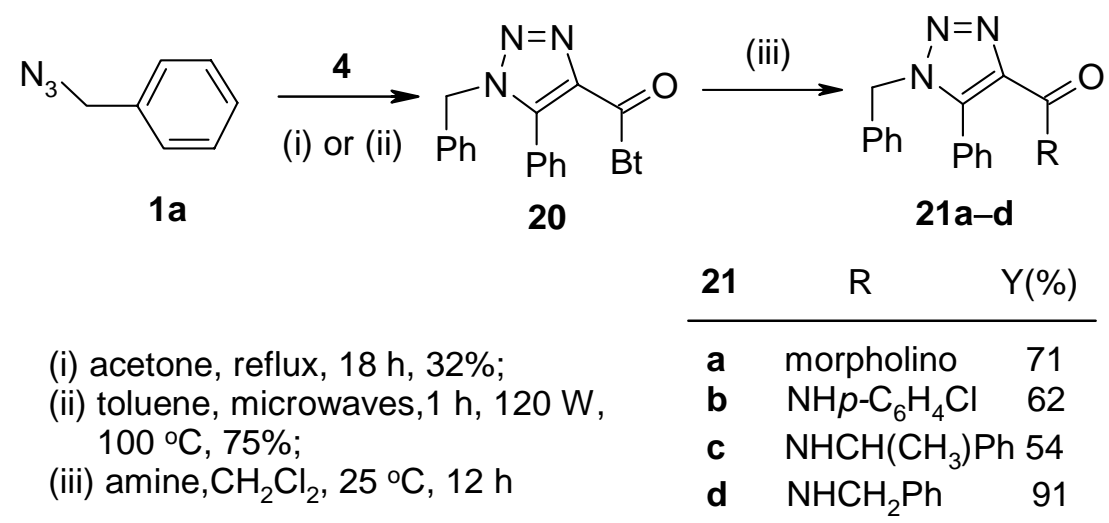

\section{Scheme 6}

\section{Conclusions}

In summary, we have introduced a convenient and general method for the preparation of substituted $C$-carbamoyl mono- and bis-triazoles by the 1,3-dipolar cycloaddition of a variety of organic azides with ester or benzotriazolylcarbonyl activated acetylenic amides under thermal or microwave reaction conditions.

\section{Experimental Section}

General Procedures. Melting points are uncorrected. All of the reactions under microwave irradiation were conducted in heavy-walled Pyrex tubes sealed with aluminum crimp caps fitted with a silicon septum. Microwave heating was carried out with a single mode cavity Discover Microwave Synthesizer (CEM Corporation, NC, USA), producing continuous irradiation at 2455 $\mathrm{MHz}$ and equipped with simultaneous external air-cooling system. ${ }^{1} \mathrm{H} \mathrm{NMR}(300 \mathrm{MHz})$ and ${ }^{13} \mathrm{C}$ NMR (75 MHz) spectra were recorded in $\mathrm{CDCl}_{3}$ (with TMS for ${ }^{1} \mathrm{H}$ and chloroform-d for ${ }^{13} \mathrm{C}$ as the internal reference) unless specified otherwise. 
Materials. Benzyl azide (1a) ${ }^{19 a}$ and 1,4-bis(azidomethyl)benzene (1) $)^{19 b}$ were prepared following a general procedure. ${ }^{20}$ 3-(Azidomethyl)-3-methyloxetane (15) was provided by Naval Air Weapons Station, China Lake, CA, USA. The preparation of 1 -(methylsulfonyl)- $1 H$-benzotriazole $(3)^{13 \mathrm{e}}$ and its reaction with phenylpropiolic acid (2) to give 1-(1H-1,2,3-benzotriazol-1-yl)-3-phenyl-2-propyn1-one (4) and subsequent reactions of 4 with morpholine (5) or 1,4-diaminocyclohexane (7) to give 1-morpholino-3-phenyl-2-propyn-1-one (6) and 3-phenyl- $N$-\{4-[(3-phenyl-2-propynoyl) amino]cyclohexyl\}-2-propynamide (8), respectively, were carried out using the previously reported general procedure. ${ }^{13 \mathrm{e}}$

1-(1H-1,2,3-Benzotriazol-1-yl)-3-phenyl-2-propyn-1-one (4). Colorless plates (from hexanes/ ethyl acetate); mp $124-125{ }^{\circ} \mathrm{C}$; yield, 50\%; ${ }^{1} \mathrm{H}$ NMR $\delta 8.32(\mathrm{~d}, J=8.2 \mathrm{~Hz}, 1 \mathrm{H}), 8.17(\mathrm{~d}, J=8.2 \mathrm{~Hz}$, $1 \mathrm{H}), 7.80(\mathrm{~d}, J=6.9 \mathrm{~Hz}, 2 \mathrm{H}), 7.70(\mathrm{t}, J=7.3 \mathrm{~Hz}, 1 \mathrm{H}), 7.55(\mathrm{t}, J=7.8 \mathrm{~Hz}, 2 \mathrm{H}), 7.44-7.49(\mathrm{~m}, 2 \mathrm{H})$; ${ }^{13} \mathrm{C}$ NMR $\delta 150.5,146.4,133.8,131.8,131.1,130.7,128.9,127.9,126.8,120.5,119.2,114.4,96.2$, 81.4. Anal. Calcd for $\mathrm{C}_{15} \mathrm{H}_{9} \mathrm{~N}_{3} \mathrm{O}: \mathrm{C}, 72.86 ; \mathrm{H}, 3.67 ; \mathrm{N}, 16.99$. Found: C, 72.73; H, 3.67; N, 16.95. 1-Morpholino-3-phenyl-2-propyn-1-one (6). ${ }^{21}$ Colorless oil; yield, 53\%; ${ }^{1} \mathrm{H}$ NMR $\delta 7.56-7.53(\mathrm{~m}$, $2 \mathrm{H}), 7.44-7.32(\mathrm{~m}, 3 \mathrm{H}), 3.86-3.83(\mathrm{~m}, 2 \mathrm{H}), 3.76-3.73(\mathrm{~m}, 2 \mathrm{H}), 3.70(\mathrm{~s}, 4 \mathrm{H}) ;{ }^{13} \mathrm{C}$ NMR $\delta 153.2$, $132.4,130.3,128.6,120.3,91.2,80.8,66.9,66.5,47.4,42.0$.

3-Phenyl- $N$-\{4-[(3-phenyl-2-propynoyl)amino]cyclohexyl\}-2-propynamide (8). White prisms (from hexanes/ethyl acetate); mp 163-164 ${ }^{\circ} \mathrm{C}$; yield, 65\%; ${ }^{1} \mathrm{H}$ NMR $\delta 7.55-7.53(\mathrm{~m}, 4 \mathrm{H}), 7.46-7.34$ $(\mathrm{m}, 6 \mathrm{H}), 5.95(\mathrm{~d}, J=6.9 \mathrm{~Hz}, 2 \mathrm{H}), 4.13-3.98(\mathrm{~m}, 2 \mathrm{H}), 1.88-1.61(\mathrm{~m}, 8 \mathrm{H}) ;{ }^{13} \mathrm{C} \mathrm{NMR} \delta 152.8,132.5$, 130.1, 128.6, 120.2, 84.6, 83.2, 46.3, 27.9. Anal. Calcd for $\mathrm{C}_{24} \mathrm{H}_{22} \mathrm{~N}_{2} \mathrm{O}_{2}$ : C, 77.81; H, 5.99; N, 7.56. Found: C, 77.75; H, 5.98; N, 7.51.

General procedure for the preparation of mono- and bis-amidopropiolates via lithiation of ethyl propiolate

Ethyl propiolate $(9)(1 \mathrm{mmol})$ was dissolved in THF $(10 \mathrm{~mL})$, the solution was cooled to $-78{ }^{\circ} \mathrm{C}$ and $n$-BuLi (1.2 mmol, 1.5M in hexanes) was added slowly. The mixture was stirred for $30 \mathrm{~min}$. and a solution of an appropriate isocyanate $(1 \mathrm{mmol})$ or diisocyanate $(0.5 \mathrm{mmol})$ in THF $(10 \mathrm{~mL})$ was added dropwise. The reaction mixture was then stirred for $2 \mathrm{~h}$ at $-78{ }^{\circ} \mathrm{C}$ and acetic acid $(1 \mathrm{~mL})$ was added to quench the reaction. The reaction mixture was allowed to warm to $25{ }^{\circ} \mathrm{C}$, water $(20 \mathrm{~mL})$ was added and the organic layer was separated. The aqueous layer was extracted with ethyl acetate. The combined organic extract was dried and removal of solvent gave a residue that was subjected to flash column chromatography on silica-gel using hexanes/ethyl acetate (4:1) as eluent to afford pure mono- or bis-amidopropiolates 11a,b or 12a-d.

Ethyl 4-anilino-4-oxo-2-butynoate (11a). Yellow oil; yield, 76\%; ${ }^{1} \mathrm{H}$ NMR $\delta 8.01$ (br s, $\left.1 \mathrm{H}\right), 7.53$ $(\mathrm{d}, J=7.6 \mathrm{~Hz}, 2 \mathrm{H}), 7.35$ (t, $J=7.8 \mathrm{~Hz}, 2 \mathrm{H}), 7.17$ (t, $J=7.4 \mathrm{~Hz}, 1 \mathrm{H}), 4.30$ (q, $J=7.1 \mathrm{~Hz}, 2 \mathrm{H}), 1.34$ $(\mathrm{t}, J=7.1 \mathrm{~Hz}, 3 \mathrm{H}) ;{ }^{13} \mathrm{C} \mathrm{NMR} \delta 152.5,148.5,136.8,129.4,125.8,120.3,77.4,74.7,63.3,14.1$. Anal. Calcd for $\mathrm{C}_{12} \mathrm{H}_{11} \mathrm{NO}_{3}$ : C, 66.35; H, 5.10; N, 6.45. Found: C, 66.09; H, 5.41; N, 6.74.

Ethyl 4-oxo-4-(4-toluidino)-2-butynoate (11b). Green needles (from hexanes/ethyl acetate); $\mathrm{mp}$ 102-103 ${ }^{\circ} \mathrm{C}$; yield, 64\%; ${ }^{1} \mathrm{H}$ NMR $\delta 8.01$ (br s, $\left.1 \mathrm{H}\right), 7.43-7.39(\mathrm{~m}, 2 \mathrm{H}), 7.13$ (d, $\left.J=8.4 \mathrm{~Hz}, 2 \mathrm{H}\right)$, 4.29 (q, $J=7.1 \mathrm{~Hz}, 2 \mathrm{H}), 2.32(\mathrm{~s}, 3 \mathrm{H}), 1.33(\mathrm{t}, J=7.1 \mathrm{~Hz}, 3 \mathrm{H}) ;{ }^{13} \mathrm{C}$ NMR $\delta 152.6,148.5,135.6$, 
134.3, 129.8, 120.4, 77.6, 74.6, 63.2, 21.1, 14.1. Anal. Calcd for $\mathrm{C}_{13} \mathrm{H}_{13} \mathrm{NO}_{3}$ : C, 67.52; H, 5.67; N, 6.06. Found: C, 67.64; H, 5.99; N, 6.02 .

Ethyl 4-\{4-[(4-ethoxy-4-oxo-2-butynoyl)amino]anilino\}-4-oxo-2-butynoate (12a). Yellow prisms (from hexanes/ethyl acetate); mp 196-197 ${ }^{\circ} \mathrm{C}$; yield, 69\%; ${ }^{1} \mathrm{H}$ NMR (DMSO- $\left.d_{6} \& \mathrm{CDCl}_{3}\right) \delta 11.05$ $(\mathrm{s}, 2 \mathrm{H}), 7.59(\mathrm{~s}, 4 \mathrm{H}), 4.30(\mathrm{q}, J=7.0 \mathrm{~Hz}, 4 \mathrm{H}), 1.33(\mathrm{t}, J=7.0 \mathrm{~Hz}, 6 \mathrm{H}) ;{ }^{13} \mathrm{C}$ NMR (DMSO- $d_{6} \&$ $\left.\mathrm{CDCl}_{3}\right) \delta 151.5,147.4,133.9,119.8,77.4,73.2,62.1,13.3$. Anal. Calcd for $\mathrm{C}_{18} \mathrm{H}_{16} \mathrm{~N}_{2} \mathrm{O}_{6}: \mathrm{C}, 60.67$; $\mathrm{H}, 4.53$; N, 7.86. Found: C, 60.76; H, 4.75; N, 7.65.

Ethyl 4-\{3-[(4-ethoxy-4-oxo-2-butynoyl)amino]-4-methylanilino\}-4-oxo-2-butynoate (12b). White prisms (from hexanes/ethyl acetate); mp $187-188{ }^{\circ} \mathrm{C}$; yield, 57\%; ${ }^{1} \mathrm{H}$ NMR $\delta 10.99$ (br s, $1 \mathrm{H}), 10.41(\mathrm{br} \mathrm{s}, 1 \mathrm{H}), 7.72(\mathrm{~d}, J=1.8 \mathrm{~Hz}, 1 \mathrm{H}), 7.46(\mathrm{dd}, J=8.5,1.8 \mathrm{~Hz}, 1 \mathrm{H}), 7.15(\mathrm{~d}, J=8.5 \mathrm{~Hz}$, $1 \mathrm{H}), 4.34-4.26(\mathrm{~m}, 4 \mathrm{H}), 2.22(\mathrm{~s}, 3 \mathrm{H}), 1.37-1.31(\mathrm{~m}, 6 \mathrm{H}) ;{ }^{13} \mathrm{C}$ NMR $\delta 151.3,148.2,147.3,135.1$, 133.6, 129.9, 128.1, 117.6, 116.1, 103.1, 77.1, 73.4, 73.0, 61.9, 16.8, 13.0. Anal. Calcd for $\mathrm{C}_{19} \mathrm{H}_{18} \mathrm{~N}_{2} \mathrm{O}_{6}$ : C, 61.62; H, 4.90; N, 7.56. Found: C, 61.59; H, 5.24; N, 7.43.

Ethyl 4-(\{6-[(4-ethoxy-4-oxo-2-butynoyl)amino]hexyl\}amino)-4-oxo-2-butynoate (12c). White prisms (from hexanes/ethyl acetate); mp $94-95^{\circ} \mathrm{C}$; yield, $40 \%$; ${ }^{1} \mathrm{H}$ NMR $\delta 6.29$ (br s, $2 \mathrm{H}$ ), 4.28 (q, $J=7.0 \mathrm{~Hz}, 4 \mathrm{H}), 3.33(\mathrm{q}, J=6.5 \mathrm{~Hz}, 4 \mathrm{H}), 1.60-1.50(\mathrm{~m}, 4 \mathrm{H}), 1.40-1.30(\mathrm{~m}, 10 \mathrm{H}) ;{ }^{13} \mathrm{C}$ NMR $\delta$ 152.5, 151.1, 77.4, 74.1, 63.1, 39.9, 29.1, 26.2, 14.1. Anal. Calcd for $\mathrm{C}_{18} \mathrm{H}_{24} \mathrm{~N}_{2} \mathrm{O}_{6}$ : C, 59.33; N, 7.69. Found: C, $59.31 ; \mathrm{N}, 7.80$.

Ethyl 4-(4-\{4-[(4-ethoxy-4-oxo-2-butynoyl)amino]benzyl\}anilino)-4-oxo-2-butynoate (12d). Yellow prisms (from hexanes/ethyl acetate); mp $133-134{ }^{\circ} \mathrm{C}$; yield, $52 \% ;{ }^{1} \mathrm{H}$ NMR $\delta 8.21$ (br s, 2H), 7.43 (d, $J=8.5 \mathrm{~Hz}, 4 \mathrm{H}), 7.10(\mathrm{~d}, J=8.5 \mathrm{~Hz}, 4 \mathrm{H}), 4.28$ (q, $J=7.0 \mathrm{~Hz}, 4 \mathrm{H}), 3.89$ (s, 2H), 1.32 (t, $J=7.0 \mathrm{~Hz}, 6 \mathrm{H}) ;{ }^{13} \mathrm{C}$ NMR $\delta 152.5,148.5,138.4,135.0,129.7,120.6,77.5,74.7,63.3,41.0$, 14.1. Anal. Calcd for $\mathrm{C}_{25} \mathrm{H}_{22} \mathrm{~N}_{2} \mathrm{O}_{6}$ : C, 67.26; H, 4.97; N, 6.27. Found: C, 67.34; H, 5.16; N, 6.09.

\section{General procedure for triazole formation under thermal conditions}

Substituted acetylene $(1 \mathrm{mmol})$ and benzyl azide (1a) $(1.2 \mathrm{mmol})$ were dissolved in acetone (20 $\mathrm{mL}$ ) and the solution was refluxed for the specified time. The solvent was removed under reduced pressure and the residue was purified by column chromatography on silica-gel using hexanes/ethyl acetate (4:1) as the eluent to give the pure triazoles. Using this procedure, acetylenic amides $\mathbf{6}, \mathbf{8}$ failed to give the corresponding triazoles on reaction with benzyl azide (1a) while the reaction of 1a with amido-propiolates $\mathbf{1 1 a}, \mathbf{b}$ or $N$-propiolylbenzotriazole 4 furnished the corresponding triazoles 13a,b or 20.

Ethyl 5-(anilinocarbonyl)-1-benzyl-1H-1,2,3-triazole-4-carboxylate (13a). White prisms (from hexanes/ethyl acetate); mp 141-142 ${ }^{\circ} \mathrm{C}$; yield, 83\%; ${ }^{1} \mathrm{H}$ NMR $\delta 11.94$ (br s, $\left.1 \mathrm{H}\right), 7.70$ (d, $J=8.0$ $\mathrm{Hz}, 2 \mathrm{H}), 7.44-7.27(\mathrm{~m}, 7 \mathrm{H}), 7.19-7.14(\mathrm{~m}, 1 \mathrm{H}),(\mathrm{t}, J=7.4 \mathrm{~Hz}, 1 \mathrm{H}), 6.19$ (s, 2H), 4.56 (q, $J=7.1$ $\mathrm{Hz}, 2 \mathrm{H}), 1.50(\mathrm{t}, J=7.1 \mathrm{~Hz}, 3 \mathrm{H}) ;{ }^{13} \mathrm{C}$ NMR $\delta 164.2,154.2,137.6,136.5,135.2,133.3,129.3,128.9$, 128.6, 125.4, 120.7, 63.4, 54.8, 14.3. Anal. Calcd for $\mathrm{C}_{19} \mathrm{H}_{18} \mathrm{~N}_{4} \mathrm{O}_{3}: \mathrm{C}, 65.13 ; \mathrm{H}, 5.18 ; \mathrm{N}, 15.99$. Found: C, 65.09; H, 5.06; N, 15.94 .

Ethyl 1-benzyl-5-(4-toluidinocarbonyl)-1H-1,2,3-triazole-4-carboxylate (13b). Green needles (from hexanes/ethyl acetate); mp $126-127{ }^{\circ} \mathrm{C}$; yield, $84 \% ;{ }^{1} \mathrm{H}$ NMR $\delta 11.84$ (br s, $\left.1 \mathrm{H}\right), 7.58(\mathrm{~d}, J=$ $8.4 \mathrm{~Hz}, 2 \mathrm{H}), 7.45-7.40(\mathrm{~m}, 2 \mathrm{H}), 7.35-7.26(\mathrm{~m}, 3 \mathrm{H}), 7.17$ (d, $J=8.1 \mathrm{~Hz}, 2 \mathrm{H}), 6.20(\mathrm{~s}, 2 \mathrm{H}), 4.56$ (q, $J=7.1 \mathrm{~Hz}, 2 \mathrm{H}), 2.34(\mathrm{~s}, 3 \mathrm{H}), 1.50(\mathrm{t}, J=7.1 \mathrm{~Hz}, 3 \mathrm{H}) ;{ }^{13} \mathrm{C} \mathrm{NMR} \delta 164.2,154.1,136.4,135.3$, 
135.1, 135.0, 133.4, 129.8, 128.9, 128.7, 128.6, 120.7, 63.4, 54.7, 21.2, 14.4. Anal. Calcd for $\mathrm{C}_{20} \mathrm{H}_{20} \mathrm{~N}_{4} \mathrm{O}_{3}$ : C, 65.92; H, 5.53; N, 15.37. Found: C, 65.79; H, 5.63; N, 15.39.

\section{General procedure for triazole formation under microwave irradiation}

A dried heavy-walled Pyrex tube containing a small stir bar was charged with mono-acetylene (1 $\mathrm{mmol})$ and mono-azide $(1.2 \mathrm{mmol})$ or bis-acetylene $(1 \mathrm{mmol})$ and mono-azide $(2.2 \mathrm{mmol})$ or monoacetylene $(2 \mathrm{mmol})$ and di-azide $(1.2 \mathrm{mmol})$. The tube containing the reaction mixture was sealed with an aluminum crimp cap fitted with a silicon septum and then it was exposed to microwave irradiation according to the conditions specified in Schemes 3 and 4. The build-up of pressure in the closed reaction vessel was carefully monitored and was found to be typically in the range 4-10 psi. After the irradiation, the reaction tube was cooled with high-pressure air through an inbuilt system in the instrument until the temperature had fallen below $40{ }^{\circ} \mathrm{C}$ ( $c a .2$ min.). The crude product was purified by column chromatography on silica-gel using hexanes/ethyl acetate (4:1) as the eluent to give the pure triazoles $\mathbf{1 4}$ and 16-20.

Bis-triazoles 19a,b were prepared by the reactions of di-azide $1 \mathbf{b}$ with acetylenes 11a,b in toluene ( $3 \mathrm{~mL} / \mathrm{mmol}$ of acetylene) with simultaneous external cooling to maintain the temperature around $75^{\circ} \mathrm{C}$ at $120 \mathrm{~W}$ microwave irradiation for $1 \mathrm{~h}$.

Ethyl 1-benzyl-5-\{[4-(\{[1-benzyl-5-(ethoxycarbonyl)-1H-1,2,3-triazol-4-yl]carbonyl\}amino)anilino]carbonyl\}-1H-1,2,3-triazole-4-carboxylate (14a'). White prisms (from hexanes/ ethyl acetate); mp $165-166{ }^{\circ} \mathrm{C}$; yield, $42 \%$; ${ }^{1} \mathrm{H}$ NMR $\delta 11.98$ (br s, $1 \mathrm{H}$ ), 9.13 (br s, $\left.1 \mathrm{H}\right), 7.70(\mathrm{~s}, 4 \mathrm{H})$, 7.44-7.22 (m, 10H), 6.20 (s. 2H), 5.81 (s, 2H), 4.57 (q, $J=7.0 \mathrm{~Hz}, 2 \mathrm{H}), 4.39$ (q, $J=7.0 \mathrm{~Hz}, 2 \mathrm{H}$ ), $1.50(\mathrm{t}, J=7.0 \mathrm{~Hz}, 3 \mathrm{H}), 1.29(\mathrm{t}, J=7.0 \mathrm{~Hz}, 3 \mathrm{H}) ;{ }^{13} \mathrm{C}$ NMR $\delta 164.3,159.3,156.5,154.1,142.9$, 136.5, 135.3, 134.7, 134.2, 133.3, 129.7, 129.4, 129.1, 128.9, 128.7, 128.1, 121.3, 120.8, 63.6, 54.8, 54.4, 14.4, 14.1. Anal. Calcd for $\mathrm{C}_{32} \mathrm{H}_{30} \mathrm{~N}_{8} \mathrm{O}_{6}$ : C, 61.73; H, 4.86; N, 18.00. Found C, 61.51; H, 4.76; $\mathrm{N}, 17.88$.

Ethyl 1-benzyl-4-\{[4-(\{[1-benzyl-5(ethoxycarbonyl)-1H-1,2,3-triazol-4-yl]carbonyl\}amino) anilino]carbonyl\}-1H-1,2,3-triazole-5-carboxylate (14a"). White microcrystals (from hexanes/ ethyl acetate); mp 203-204 ${ }^{\circ} \mathrm{C}$; yield, 37\%; ${ }^{1} \mathrm{H}$ NMR $\delta 9.12(\mathrm{~s}, 2 \mathrm{H}), 7.68(\mathrm{~s}, 4 \mathrm{H}), 7.35-7.33(\mathrm{~m}$, $6 \mathrm{H}), 7.26-7.20(\mathrm{~m}, 4 \mathrm{H}), 5.80(\mathrm{~s}, 4 \mathrm{H}), 4.38(\mathrm{q}, J=7.1 \mathrm{~Hz}, 4 \mathrm{H}), 1.29(\mathrm{t}, J=7.1 \mathrm{~Hz}, 6 \mathrm{H}) ;{ }^{13} \mathrm{C}$ NMR $\delta$ 159.3, 156.5, 142.9, 134.2, 134.2, 129.7, 129.2, 129.1, 128.1, 120.8, 63.4, 54.3, 14.0. Anal. Calcd for $\mathrm{C}_{32} \mathrm{H}_{30} \mathrm{~N}_{8} \mathrm{O}_{6}: \mathrm{C}, 61.73 ; \mathrm{H}, 4.86 ; \mathrm{N}, 18.00$. Found $\mathrm{C}, 60.94 ; \mathrm{H}, 5.00 ; \mathrm{N}, 17.57$.

Ethyl 1-benzyl-5-\{[5-(\{[1-benzyl-4-(ethoxycarbonyl)-1H-1,2,3-triazol-5-yl]carbonyl\}ami-no)-2methylanilino]carbonyl\}-1 H-1,2,3-triazole-4-carboxylate (14b). White prisms (from hexanes /ethyl acetate); mp $189-190{ }^{\circ} \mathrm{C}$; yield, $41 \%$; ${ }^{1} \mathrm{H}$ NMR $\delta 11.92$ (br s, $\left.1 \mathrm{H}\right), 11.39$ (br s, $1 \mathrm{H}$ ), 8.15 (s, $1 \mathrm{H}), 7.51-7.41(\mathrm{~m}, 5 \mathrm{H}), 7.34-7.21(\mathrm{~m}, 7 \mathrm{H}), 6.21(\mathrm{~s}, 2 \mathrm{H}), 6.20(\mathrm{~s}, 2 \mathrm{H}), 4.60-4.51(\mathrm{~m}, 4 \mathrm{H}), 2.29(\mathrm{~s}$, $3 \mathrm{H}), 1.53-1.47(\mathrm{~m}, 6 \mathrm{H}) ;{ }^{13} \mathrm{C}$ NMR $\delta 164.2,163.9,155.0,154.2,135.8,135.4,135.2,131.4,128.9$, $128.8,128.6,128.4,118.7,116.7,63.4,54.9,54.8,29.9,18.1,14.4$. HRMS calcd for $\mathrm{C}_{33} \mathrm{H}_{33} \mathrm{~N}_{8} \mathrm{O}_{6}$ 637.2523, found 637.2478.

Ethyl 5-(\{[6-(\{[4-(ethoxycarbonyl)-1-phenyl-1H-1,2,3-triazol-5-yl]carbonyl\}amino)hexyl] amino\}carbonyl)-1-phenyl-1H-1,2,3-triazole-4-carboxylate (14c). White prisms (from hexanes/ ethyl acetate); mp $96-97{ }^{\circ} \mathrm{C}$; yield, 37\%; ${ }^{1} \mathrm{H}$ NMR $\delta 9.77$ (br s, 2H), 7.37-7.27 (m, 10H), 6.12 (s, 
4H), $4.49(\mathrm{q}, J=7.1 \mathrm{~Hz}, 4 \mathrm{H}), 3.42-3.35(\mathrm{~m}, 4 \mathrm{H}), 1.62-1.58(\mathrm{~m}, 4 \mathrm{H}), 1.46(\mathrm{t}, J=7.1 \mathrm{~Hz}, 6 \mathrm{H})$, $1.41-1.38(\mathrm{~m}, 4 \mathrm{H}) ;{ }^{13} \mathrm{C} \mathrm{NMR} \delta 163.5,156.2,136.4,135.2,132.8,128.6,128.2,62.8,54.3,39.6$, 28.8, 26.4, 14.1. Anal. Calcd for $\mathrm{C}_{32} \mathrm{H}_{38} \mathrm{~N}_{8} \mathrm{O}_{6}$ : C, 60.94; H, 6.07; N, 17.77. Found C, 61.44; H, 6.11; N, 17.70 .

Ethyl 1-benzyl-5-\{[4-(4-[(1-benzyl-4-ethoxycarbonyl-1H-1,2,3-triazol-5-yl)carbonyl]amino benzyl)anilino]carbonyl\}-1H-1,2,3-triazole-4-carboxylate (14d). White prisms (from hexanes/ethyl acetate); mp 194-195 ${ }^{\circ} \mathrm{C}$; yield, 73\%; ${ }^{1} \mathrm{H}$ NMR $\delta 11.88(\mathrm{~s}, 2 \mathrm{H}), 7.61$ (d, $J=8.5 \mathrm{~Hz}$, 4H), 7.42-7.39 (m, 4H), 7.34-7.28 (m, 6H), $7.18(\mathrm{~d}, J=8.5 \mathrm{~Hz}, 4 \mathrm{H}), 6.19(\mathrm{~s}, 4 \mathrm{H}), 4.56(\mathrm{q}, J=7.3$ $\mathrm{Hz}, 4 \mathrm{H}), 3.96(\mathrm{~s}, 2 \mathrm{H}), 1.49(\mathrm{t}, J=7.3 \mathrm{~Hz}, 6 \mathrm{H}) ;{ }^{13} \mathrm{C}$ NMR $\delta 164.2,154.1,138.1,136.5,135.7,135.3$, 133.3, 129.7, 128.9, 128.6, 120.9, 63.5, 54.8, 41.1, 14.4. HRMS calcd for $\mathrm{C}_{39} \mathrm{H}_{37} \mathrm{~N}_{8} \mathrm{O}_{6} 713.2836$, found 713.2820 .

Ethyl 5-(anilinocarbonyl)-1-[(3-methyl-3-oxetanyl)methyl]-1H-1,2,3-triazole-4-carboxy-

late (16a). White prisms (from hexanes/ethyl acetate); mp $135-136{ }^{\circ} \mathrm{C}$; yield, $72 \%$; ${ }^{1} \mathrm{H}$ NMR $\delta$ 12.07 (br s, 1H), 7.72 (d, $J=7.8 \mathrm{~Hz}, 2 \mathrm{H}), 7.42-7.37$ (t, $J=7.8 \mathrm{~Hz}, 2 \mathrm{H}), 7.20(\mathrm{t}, J=7.4 \mathrm{~Hz}, 1 \mathrm{H})$, $5.25(\mathrm{~s}, 2 \mathrm{H}), 4.74(\mathrm{~d}, J=6.5 \mathrm{~Hz}, 2 \mathrm{H}), 4.59(\mathrm{q}, J=7.1 \mathrm{~Hz}, 2 \mathrm{H}), 4.39(\mathrm{~d}, J=6.5 \mathrm{~Hz}, 2 \mathrm{H}), 1.52(\mathrm{t}, J=$ $7.1 \mathrm{~Hz}, 3 \mathrm{H}), 1.36(\mathrm{~s}, 3 \mathrm{H}) ;{ }^{13} \mathrm{C}$ NMR $\delta 164.3,154.6,137.5,136.2,134.2,129.4,125.6,120.8,80.3$, 63.6, 56.4, 41.1, 22.1, 14.3. Anal. Calcd for $\mathrm{C}_{17} \mathrm{H}_{20} \mathrm{~N}_{4} \mathrm{O}_{4}$ : C, 59.29; H, 5.85; N, 16.27. Found: C, $59.43 ; \mathrm{H}, 6.17 ; \mathrm{N}, 16.06$.

Ethyl 1-[(3-methyl-3-oxetanyl)methyl]-5-(4-toluidinocarbonyl)-1H-1,2,3-triazole-4-carboxylate (16b). White microcrystals (from hexanes/ethyl acetate); mp $124-125{ }^{\circ} \mathrm{C}$; yield, $53 \% ;{ }^{1} \mathrm{H}$ NMR $\delta 11.99$ (br s, 1H), 7.59 (d, $J=8.1 \mathrm{~Hz}, 2 \mathrm{H}), 7.19$ (d, $J=8.1 \mathrm{~Hz}, 2 \mathrm{H}), 5.24$ (s, 2H), 4.74 (d, $J=$ $6.3 \mathrm{~Hz}, 2 \mathrm{H}), 4.58(\mathrm{q}, J=7.0 \mathrm{~Hz}, 2 \mathrm{H}), 4.38(\mathrm{~d}, J=6.3 \mathrm{~Hz}, 2 \mathrm{H}), 2.35(\mathrm{~s}, 3 \mathrm{H}), 1.52(\mathrm{t}, J=7.0 \mathrm{~Hz}$, $3 \mathrm{H}), 1.36(\mathrm{~s}, 3 \mathrm{H}) ;{ }^{13} \mathrm{C}$ NMR $\delta 164.0,154.2,135.9,135.1,134.6,134.0,129.6,120.5,80.1,63.3$, 56.1, 40.9, 21.9, 21.0, 14.1. Anal. Calcd for $\mathrm{C}_{18} \mathrm{H}_{22} \mathrm{~N}_{4} \mathrm{O}_{4}$ : C, 60.32; H, 6.19; N, 15.63. Found: C, $60.65 ; \mathrm{H}, 6.27 ; \mathrm{N}, 15.54$.

Ethyl 5-\{[4-(\{[4-(ethoxycarbonyl)-1-[(3-methyl-3-oxetanyl)methyl]-1H-1,2,3-triazol-5-yl] carbonyl\}amino)anilino]carbonyl $\}$-1-[(3-methyl-3-oxetanyl)methyl]-1H-1,2,3-triazole-4-

carboxylate (17a). White microcrystals (from hexanes/ethyl acetate); mp $245-246{ }^{\circ} \mathrm{C}$; yield, $43 \%$; ${ }^{1} \mathrm{H}$ NMR $\delta 12.17(\mathrm{~s}, 2 \mathrm{H}), 7.76(\mathrm{~s}, 4 \mathrm{H}), 5.25(\mathrm{~s}, 4 \mathrm{H}), 4.75(\mathrm{~d}, J=6.3 \mathrm{~Hz}, 4 \mathrm{H}), 4.60$ (q, $J=7.1 \mathrm{~Hz}$, $4 \mathrm{H}), 4.40(\mathrm{~d}, J=6.3 \mathrm{~Hz}, 4 \mathrm{H}), 1.53(\mathrm{t}, J=7.1 \mathrm{~Hz}, 6 \mathrm{H}), 1.37(\mathrm{~s}, 6 \mathrm{H}) ;{ }^{13} \mathrm{C} \mathrm{NMR} \delta 164.4,154.5,136.2$, 134.7, 134.1, 121.4, 80.3, 63.7, 56.4, 41.1, 22.1, 14.3. Anal. Calcd for $\mathrm{C}_{28} \mathrm{H}_{34} \mathrm{~N}_{8} \mathrm{O}_{8}$ : C, 55.08; $\mathrm{H}$, 5.61. Found C, 54.93; H, 5.90 .

Ethyl 5-\{[4-(4-\{[4-ethoxycarbonyl-1-[(3-methyl-3-oxetanyl)methyl]-1H-1,2,3-triazol-5-yl) carbonyl]amino\}benzyl)anilino]carbonyl\}-1-[(3-methyl-3-oxetanyl)methyl]-1H-1,2,3-triazole4-carboxylate (17b). White microcrystals (from hexanes/ethyl acetate); mp 237-238 ${ }^{\circ} \mathrm{C}$; yield, $42 \%$; ${ }^{1} \mathrm{H}$ NMR $\delta 12.04(\mathrm{~s}, 2 \mathrm{H}), 7.63(\mathrm{~d}, J=8.4 \mathrm{~Hz}, 4 \mathrm{H}), 7.20(\mathrm{~d}, J=8.4 \mathrm{~Hz}, 4 \mathrm{H}), 5.24(\mathrm{~s}, 4 \mathrm{H}), 4.73(\mathrm{~d}, J$ $=6.5 \mathrm{~Hz}, 4 \mathrm{H}), 4.58(\mathrm{q}, J=7.1 \mathrm{~Hz}, 4 \mathrm{H}), 4.38(\mathrm{~d}, J=6.5 \mathrm{~Hz}, 4 \mathrm{H}), 3.98(\mathrm{~s}, 2 \mathrm{H}), 1.52(\mathrm{t}, J=7.1 \mathrm{~Hz}$, $6 \mathrm{H}), 1.36(\mathrm{~s}, 6 \mathrm{H}) ;{ }^{13} \mathrm{C}$ NMR $\delta 164.0,154.3,138.1,135.9,135.4,133.9,129.5,120.7,80.1,63.3$, 56.1, 40.8, 21.9, 14.1. Anal. Calcd for $\mathrm{C}_{35} \mathrm{H}_{40} \mathrm{~N}_{8} \mathrm{O}_{8}$ : C, 59.99; H, 5.75. Found C, 60.13; H, 6.19.

Ethyl 5-(anilinocarbonyl)-1-[4-(azidomethyl)benzyl]-1H-1,2,3-triazole-4-carboxylate(18a). White prisms (from hexanes/ethyl acetate); mp 101-102 ${ }^{\circ} \mathrm{C}$; yield, 60\%; ${ }^{1} \mathrm{H}$ NMR $\delta 11.97$ (br s, $1 \mathrm{H}), 7.70(\mathrm{~d}, J=8.5 \mathrm{~Hz}, 2 \mathrm{H}), 7.44(\mathrm{~d}, J=7.9 \mathrm{~Hz}, 2 \mathrm{H}), 7.40-7.35(\mathrm{~m}, 2 \mathrm{H}), 7.27(\mathrm{~d}, J=7.9 \mathrm{~Hz}, 2 \mathrm{H})$, 
$7.18(\mathrm{t}, J=7.6 \mathrm{~Hz}, 1 \mathrm{H}), 6.20(\mathrm{~s}, 2 \mathrm{H}), 4.57(\mathrm{q}, J=7.0 \mathrm{~Hz}, 2 \mathrm{H}), 4.30(\mathrm{~s}, 2 \mathrm{H}), 1.51(\mathrm{t}, J=7.0 \mathrm{~Hz}, 3 \mathrm{H})$; ${ }^{13} \mathrm{C}$ NMR $\delta 164.2,154.1,137.5,136.5,135.9,135.3,133.3,129.3,129.1,128.7,125.4,120.7,63.5$, 54.5, 54.4, 14.4. Anal. Calcd for $\mathrm{C}_{20} \mathrm{H}_{19} \mathrm{~N}_{7} \mathrm{O}_{3}$ : C, 59.25; H, 4.72; N, 24.18. Found C, 59.16; H, 4.98; N, 23.74 .

Ethyl 4-(anilinocarbonyl)-1-[4-(azidomethyl)benzyl]-1H-1,2,3-triazole-5-carboxylate (18a'). White prisms (from hexanes/ethyl acetate); mp 96-97 ${ }^{\circ} \mathrm{C}$; yield, $12 \%$; ${ }^{1} \mathrm{H}$ NMR $\delta 9.07$ (br s, $1 \mathrm{H}), 7.67(\mathrm{~d}, J=8.0 \mathrm{~Hz}, 2 \mathrm{H}), 7.39-7.29(\mathrm{~m}, 6 \mathrm{H}), 7.15$ (t, $J=7.4 \mathrm{~Hz}, 1 \mathrm{H}), 5.81(\mathrm{~s}, 2 \mathrm{H}), 4.40(\mathrm{q}, J=$ $7.1 \mathrm{~Hz}, 2 \mathrm{H}), 4.33(\mathrm{~s}, 2 \mathrm{H}), 1.31(\mathrm{t}, J=7.1 \mathrm{~Hz}, 3 \mathrm{H}) ;{ }^{13} \mathrm{C} \mathrm{NMR} \delta 159.2,156.6,143.0,137.6,136.4$, 134.3, 129.3, 129.0, 128.6, 124.9, 120.2, 63.5, 54.4, 53.9, 14.1. Anal. Calcd for $\mathrm{C}_{20} \mathrm{H}_{19} \mathrm{~N}_{7} \mathrm{O}_{3}: \mathrm{C}$, 59.25; H, 4.72; N, 24.18. Found C, 59.20; H, 4.75; N, 23.71.

Ethyl 1-[4-(azidomethyl)benzyl]-5-(4-toluidinocarbonyl)-1H-1,2,3-triazole-4-carboxylate (18b). White prisms (from hexanes/ethyl acetate); mp 119-120 ${ }^{\circ} \mathrm{C}$; yield, 54\%; ${ }^{1} \mathrm{H}$ NMR $\delta 11.88$ (br s, $1 \mathrm{H}), 7.58(\mathrm{~d}, J=8.4 \mathrm{~Hz}, 2 \mathrm{H}), 7.44(\mathrm{~d}, J=8.1 \mathrm{~Hz}, 2 \mathrm{H}), 7.26(\mathrm{~d}, J=8.0 \mathrm{~Hz}, 2 \mathrm{H}), 7.17(\mathrm{~d}, J=8.2 \mathrm{~Hz}$, 2H), 6.19 (s, 2H), 4.56 (q, J=7.1 Hz, 2H), 4.29 (s, 2H), $2.34(\mathrm{~s}, 3 \mathrm{H}), 1.50(\mathrm{t}, J=7.1 \mathrm{~Hz}, 3 \mathrm{H}) ;{ }^{13} \mathrm{C}$ NMR $\delta 164.2,154.0,136.5,135.9,135.4,135.2,135.0,133.4,129.8,129.2,128.7,120.7,63.4$, 54.5, 54.4, 21.2, 14.4. Anal. Calcd for $\mathrm{C}_{21} \mathrm{H}_{21} \mathrm{~N}_{7} \mathrm{O}_{3}$ : C, 60.13; H, 5.05; N, 23.38. Found C, 60.22; $\mathrm{H}$, $5.21 ; \mathrm{N}, 23.22$.

Ethyl 1-[4-(azidomethyl)benzyl]-4-(4-toluidinocarbonyl)-1H-1,2,3-triazole-5-carboxylate (18b'). White prisms (from hexanes/ethyl acetate); mp $84-85{ }^{\circ} \mathrm{C}$; yield, $18 \%$; ${ }^{1} \mathrm{H}$ NMR $\delta 9.02$ (br s, 1H), $7.56(\mathrm{~d}, J=8.4 \mathrm{~Hz}, 2 \mathrm{H}), 7.32-7.26(\mathrm{~m}, 4 \mathrm{H}), 7.16(\mathrm{~d}, J=8.3 \mathrm{~Hz}, 2 \mathrm{H}), 5.80(\mathrm{~s}, 2 \mathrm{H}), 4.39(\mathrm{q}, J=7.1$ $\mathrm{Hz}, 2 \mathrm{H}), 4.33$ (s, 2H), 2.33 (s, 3H), 1.30 (t, $J=7.1 \mathrm{~Hz}, 3 \mathrm{H}) ;{ }^{13} \mathrm{C}$ NMR $\delta 159.1,156.3,143.0,136.2$, $134.8,134.4,134.1,129.6,129.4,128.8,128.4,120.0,63.3,54.2,53.7,20.9,13.9$. Anal. Calcd for $\mathrm{C}_{21} \mathrm{H}_{21} \mathrm{~N}_{7} \mathrm{O}_{3}: \mathrm{C}, 60.13 ; \mathrm{H}, 5.05 ; \mathrm{N}, 23.38$. Found $\mathrm{C}, 60.26 ; \mathrm{H}, 5.31 ; \mathrm{N}, 23.25$.

Ethyl 1-[4-(\{5-(ethoxycarbonyl)-4-[(phenylamino)carbonyl]-1H-1,2,3-triazol-1-yl\} methyl) benzyl]-5-[(phenylamino)carbonyl]-1H-1,2,3-triazole-4-carboxylate (19a). White micro-crystals (from hexanes/ethyl acetate); mp $162-163{ }^{\circ} \mathrm{C}$; yield, 54\%; ${ }^{1} \mathrm{H}$ NMR $\delta 11.98(\mathrm{~s}, 1 \mathrm{H}), 9.07(\mathrm{~s}, 1 \mathrm{H})$, 7.69-7.64 (m, 4H), 7.42-7.32 (m, 6H), 7.22-7.10 (m, 4H), $6.16(\mathrm{~s}, 2 \mathrm{H}), 5.74(\mathrm{~s}, 2 \mathrm{H}), 4.56(\mathrm{q}, J=$ $7.0 \mathrm{~Hz}, 2 \mathrm{H}), 4.32(\mathrm{q}, J=7.1 \mathrm{~Hz}, 2 \mathrm{H}), 1.49(\mathrm{t}, J=7.1 \mathrm{~Hz}, 3 \mathrm{H}), 1.22(\mathrm{t}, J=7.0 \mathrm{~Hz}, 3 \mathrm{H}) ;{ }^{13} \mathrm{C}$ NMR $\delta$ $164.1,159.1,156.5,154.1,143.0,137.5,137.5,136.5,136.0,134.4,133.3,129.5,129.3,129.2$, 129.0, 128.5, 125.4, 124.8, 120.6, 120.1, 63.5, 63.4, 54.3, 53.8, 14.3, 13.9. Anal. Calcd for $\mathrm{C}_{32} \mathrm{H}_{30} \mathrm{~N}_{8} \mathrm{O}_{6}$ : C, 61.73; H, 4.86. Found C, 61.67; H, 5.50.

Ethyl 1-(4-\{[4-(ethoxycarbonyl)-5-(4-toluidinoaminocarbonyl)-1H-1,2,3-triazol-1-yl]methyl\}benzyl)-5-[(4-toluidinoamino)carbonyl]-1H-1,2,3-triazole-4-carboxylate (19b). White microcrystals (from hexanes/ethyl acetate); mp 227-228 ${ }^{\circ} \mathrm{C}$; yield, 65\%; ${ }^{1} \mathrm{H}$ NMR $\delta 11.84$ (br s, 2H), 7.54 $(\mathrm{d}, J=8.4 \mathrm{~Hz}, 4 \mathrm{H}), 7.36(\mathrm{~s}, 4 \mathrm{H}), 7.15(\mathrm{~d}, J=8.4 \mathrm{~Hz}, 4 \mathrm{H}), 6.14(\mathrm{~s}, 4 \mathrm{H}), 4.54(\mathrm{q}, J=7.1 \mathrm{~Hz}, 4 \mathrm{H})$, $2.33(\mathrm{~s}, 6 \mathrm{H}), 1.48(\mathrm{t}, J=7.0 \mathrm{~Hz}, 6 \mathrm{H}) ;{ }^{13} \mathrm{C} \mathrm{NMR} \delta 164.0,153.8,136.2,135.3,134.9,134.7,133.2$, 129.6, 128.8, 120.4, 63.2, 54.1, 21.0, 14.1. Anal. Calcd for $\mathrm{C}_{34} \mathrm{H}_{34} \mathrm{~N}_{8} \mathrm{O}_{6}$ : C, 62.76; H, 5.27; N, 17.22. Found C, 62.60; H, 5.28; N, 17.08 .

1H-1,2,3-Benzotriazol-1-yl(1-benzyl-5-phenyl-1H-1,2,3-triazol-4-yl)methanone (20). White plates (from hexanes/ethyl acetate); mp $145-147{ }^{\circ} \mathrm{C}$; yield, $75 \%$; ${ }^{1} \mathrm{H}$ NMR $\delta 8.23$ (d, $J=8.2 \mathrm{~Hz}$, $1 \mathrm{H}), 8.11(\mathrm{~d}, J=8.2 \mathrm{~Hz}, 1 \mathrm{H}), 7.63$ (t, $J=7.9 \mathrm{~Hz}, 1 \mathrm{H}), 7.52-7.40(\mathrm{~m}, 4 \mathrm{H}), 7.31-7.26(\mathrm{~m}, 5 \mathrm{H})$, 
7.15-7.05 (m, 2H), 5.55 (s, 2H); ${ }^{13} \mathrm{C}$ NMR $\delta 159.7,146.0,142.9,138.4,134.4,131.9,130.6,130.4$, 129.8, 129.1, 128.8, 127.9, 126.5, 125.5, 120.4, 114.4, 52.6. Anal. Calcd for $\mathrm{C}_{22} \mathrm{H}_{16} \mathrm{~N}_{6} \mathrm{O}: \mathrm{C}, 69.46$; H, 4.24; N, 22.09. Found C, 69.50; H, 4.32; N, 22.21.

\section{General procedure for the reaction of benzotriazolylcarbonyltriazole 20 with amines}

A solution of $1 H$-1,2,3-benzotriazol-1-yl(1-benzyl-5-phenyl-1H-1,2,3-triazol-4-yl)methanone (20) $(0.38 \mathrm{~g}, 1 \mathrm{mmol})$ with an appropriate amine $(1 \mathrm{mmol})$ in $\mathrm{CH}_{2} \mathrm{Cl}_{2}(5 \mathrm{~mL})$ was stirred at $25{ }^{\circ} \mathrm{C}$ for 12 h. Ethyl acetate $(50 \mathrm{~mL})$ was added and aqueous work-up gave the crude product which was purified by flash column chromatography on silica-gel using hexanes/ethyl acetate (3:1) to afford the $C$-carbamoyl triazoles $21 \mathbf{a}-\mathbf{d}$.

(1-Benzyl-5-phenyl-1H-1,2,3-triazol-4-yl)(morpholino)methanone (21a). White prisms (from hexanes/ethyl acetate); mp $129-130{ }^{\circ} \mathrm{C}$; yield, $71 \%$; ${ }^{1} \mathrm{H}$ NMR $\delta$ 7.48-7.41 (m, 3H), 7.29-7.25 (m, 5H), 7.05-7.02 (m, 2H), 5.44 (s, 2H), 3.87 (br s, 2H), 3.70-3.60 (m, 6H); ${ }^{13} \mathrm{C}$ NMR $\delta$ 161.1, 140.1, 139.7, 134.9, 130.2, 129.9, 129.0, 129.0, 128.6, 127.8, 126.4, 67.3, 67.0, 52.3, 47.9, 42.9. Anal. Calcd for $\mathrm{C}_{20} \mathrm{H}_{20} \mathrm{~N}_{4} \mathrm{O}_{2}$ : C, 68.95; H, 5.79; N, 16.08. Found C, 68.91; H, 6.04; N, 16.08.

1-Benzyl- $N$-(4-chlorophenyl)-5-phenyl-1H-1,2,3-triazole-4-carboxamide (21b). White microcrystals (from hexanes/ethyl acetate); mp $133-134{ }^{\circ} \mathrm{C}$; yield, $62 \% ;{ }^{1} \mathrm{H}$ NMR $\delta 9.13(\mathrm{~s}, 1 \mathrm{H}), 7.60(\mathrm{~d}$, $J=8.8 \mathrm{~Hz}, 2 \mathrm{H}), 7.50-7.43(\mathrm{~m}, 3 \mathrm{H}), 7.30-7.24(\mathrm{~m}, 7 \mathrm{H}), 7.05-7.00(\mathrm{~m}, 2 \mathrm{H}), 5.44(\mathrm{~s}, 2 \mathrm{H}) ;{ }^{13} \mathrm{C} \mathrm{NMR}$ $\delta 158.2,140.2,138.9,136.4,134.7,130.4,130.1,129.3,129.1,129.1,128.8,128.7,127.7,125.8$, 121.1, 52.4. Anal. Calcd for $\mathrm{C}_{22} \mathrm{H}_{17} \mathrm{ClN}_{4} \mathrm{O}: \mathrm{C}, 67.95 ; \mathrm{H}, 4.41 ; \mathrm{N}, 14.41$. Found $\mathrm{C}, 68.14 ; \mathrm{H}, 4.43 ; \mathrm{N}$, 14.33 .

1-Benzyl-5-phenyl- $N$-(1-phenylethyl)-1H-1,2,3-triazole-4-carboxamide (21c). White plates (from hexanes/ethyl acetate); $\mathrm{mp} 152-153{ }^{\circ} \mathrm{C}$; yield, $54 \%$; ${ }^{1} \mathrm{H}$ NMR $\delta 7.60-7.56(\mathrm{~m}, 2 \mathrm{H}), 7.38-7.23$ $(\mathrm{m}, 11 \mathrm{H}), 7.02-6.98(\mathrm{~m}, 2 \mathrm{H}), 5.88-5.83(\mathrm{~m}, 3 \mathrm{H}), 5.21-5.11(\mathrm{~m}, 1 \mathrm{H}), 1.29(\mathrm{~d}, J=6.9 \mathrm{~Hz}, 3 \mathrm{H}) ;{ }^{13} \mathrm{C}$ NMR $\delta 158.1,146.5,141.8,135.5,129.8,129.4,129.1,129.0,128.9,128.6,127.8,127.4,126.3$, 53.6, 49.3, 21.2. Anal. Calcd for $\mathrm{C}_{24} \mathrm{H}_{22} \mathrm{~N}_{4} \mathrm{O}: \mathrm{C}, 75.37 ; \mathrm{H}, 5.80 ; \mathrm{N}, 14.65$. Found C, 75.61; H, 6.15; $\mathrm{N}, 14.82$.

N,1-Dibenzyl-5-phenyl-1H-1,2,3-triazole-4-carboxamide (21d). White prisms (from hexanes/ ethyl acetate); mp 128-129 ${ }^{\circ} \mathrm{C}$; yield, 91\%; ${ }^{1} \mathrm{H}$ NMR $\delta 7.57$ (br s, $\left.1 \mathrm{H}\right), 7.47-7.40(\mathrm{~m}, 3 \mathrm{H})$, 7.33-7.25 (m, 10H), 7.02-7.00 (m, 2H), $5.42(\mathrm{~s}, 2 \mathrm{H}), 4.57(\mathrm{~d}, J=6.1 \mathrm{~Hz}, 2 \mathrm{H}) ;{ }^{13} \mathrm{C}$ NMR $\delta 160.2$, 139.6, 139.0, 138.2, 134.9, 130.2, 129.0, 128.9, 128.7, 128.6, 128.1, 127.7, 126.1, 52.3, 43.2. Anal. Calcd for $\mathrm{C}_{23} \mathrm{H}_{20} \mathrm{~N}_{4} \mathrm{O}: \mathrm{C}, 74.98 ; \mathrm{H}, 5.47 ; \mathrm{N}, 15.21$. Found C, 74.62; H, 5.44; N, 15.09 .

\section{X-Ray Crystallography}

Data were collected with a Siemens SMART CCD area detector, using graphite monochromatized MoK $\alpha$ radiation $\left(\lambda=0.71073 \AA\right.$ ). The structure was solved by direct methods using SHELXS ${ }^{22}$ and refined on $\mathrm{F}^{2}$, using all data, by full-matrix least-squares procedures using SHELXTL ${ }^{23}$ Hydrogen atoms were included in calculated positions, with isotropic displacement parameters 1.2 times the isotropic equivalent of their carrier carbons, except for the $\mathrm{NH}$ hydrogen which was found in a difference map and its position refined.

Crystal data for 13a: $\mathrm{C}_{19} \mathrm{H}_{18} \mathrm{~N}_{4} \mathrm{O}_{3}$, MW 350.37, monoclinic, $\mathrm{P}_{1} / \mathrm{c}, a=5.6619(6), b=22.918(3)$, $c=13.232(2) \AA, \beta=99.670(2)^{\circ}, \mathrm{V}=1692.6(2) \AA^{3}, \mathrm{Z}=4, \mathrm{~T}=-110^{\circ} \mathrm{C}, \mathrm{F}(000)=736, \mu(\mathrm{MoK} \alpha)=$ 
$0.096 \mathrm{~mm}^{-1}, \mathrm{D}_{\text {calcd }}=1.375 \mathrm{~g} \cdot \mathrm{cm}^{-3}, 2 \theta_{\max } 50^{\circ}(\mathrm{CCD}$ area detector, $99.9 \%$ completeness $), \mathrm{wR}\left(\mathrm{F}^{2}\right)=$ 0.0806 (all 2979 data), $\mathrm{R}=0.0385$ (1786 data with $\mathrm{I}>2 \sigma \mathrm{I})$.

\section{Supplementary Information}

See Table 1 on page 143. Crystal data and structure refinement for 13a.

See Table 2 on page 144. Atomic coordinates ( $x$ 104) and equivalent isotropic displacement parameters $\left(\AA_{2} \mathrm{x} 10_{3}\right)$ for $13 \mathrm{a}$. U(eq) is defined as one third of the trace of the orthogonalized $\mathrm{U}_{\mathrm{ij}}$ tensor.

See Table 3 on page 145. Bond lengths $[\AA]$ and angles $\left[^{\circ}\right]$ for $13 \mathrm{a}$.

See Table 4 on page 149. Anisotropic displacement parameters $\left(\AA_{2 x} 10_{3}\right)$ for 13a. The anisotropic displacement factor exponent takes the form: $-2 \pi_{2}\left[h_{2} a_{2} U_{11}+\ldots+2 h k\right.$ a* b* $\left.U_{12}\right]$

See Table 5 on page 150. Hydrogen coordinates ( $x$ 104) and isotropic displacement parameters $\left(\AA_{2 \times} 10_{3}\right)$ for $13 \mathrm{a}$.

\section{Acknowledgments}

Financial support for this work from the Office of Naval Research under Grant No. 166626712 is gratefully acknowledged. We thank Dr. Clifford D. Bedford (Office of Naval Research, VA), Dr. David A. Ciaramitaro (Naval Air Weapons Station, CA) and Dr. Michael J. Collins (CEM, NC) for very helpful discussions and the CEM Corporation for providing the Discover microwave synthesizer.

\section{References}

1. (a) Sanghvi, Y. S.; Bhattacharya, B. K.; Kini, G. D.; Matsumoto, S. S.; Larson, S. B.; Jolley, W. B.; Robins, R. K.; Revankar, G. R. J. Med. Chem. 1990, 33, 336. (b) Hupe, D. J.; Botz, R.; Cohen, C. J.; Felix, J.; Ham, E.; Miller, D.; Soderman, D.; Van Skiver, D. J. Biol. Chem. 1991, 266, 10136. (c) Bascal, A.; Holden-Dye, L.; Willis, R. J.; Smith, S. W. G.; Walker, R. J. J. Parasitology 1996, 112, 253. (d) Biagi, G.; Giorgi, I.; Livi, O.; Lucacchini, A.; Martini, C.; Scartoni, V. J. Pharm. Sci. 1993, 82, 893.

2. (a) Peto, C.; Batta, G.; Gyorgydeak, Z.; Sztaricskai, F. J. Carbohyd. Chem. 1996, 15, 465. (b) Kume, M.; Kubota, T.; Kimura, Y.; Nakashimizu, H.; Motokawa, K.; Nakano, M. J. Antibiot. 1993, 46, 177. (c) Moltzen, E. K.; Pedersen, H.; Bogeso, K. P.; Meier, E.; Frederiksen, K.; Sanchez, C.; Lembol, H. L. J. Med. Chem. 1994, 37, 4085. (d) Norris, P.; Horton, D.; Levine, B. R. Heterocycles 1996, 43, 2643. 
3. (a) Fan, W.-Q.; Katritzky, A. R. In Comprehensive Heterocyclic Chemistry; Katritzky, A. R.; Rees, C. W.; Scriven, E. F. V., Eds.; Pergamon Press: New York, 1984; Vol. 4, pp 101. (b) Boddy, I. K.; Briggs, G. G.; Harrison, R. P.; Jones, T. H.; O’Mahony, M. J.; Marlow, I. D.; Roberts, B. G.; Willis, R. J.; Bardsley, R.; Reid, J. Pestic. Sci. 1996, 48, 189.

4. (a) Reed, R. Jr. US Pat. 6103029, 2000; Chem. Abstr. 2000, 133, 152741. (b) Thompson, C. M.; Hergenrother, P. M. High Perform. Polym. 2001, 13, 313; Chem. Abstr. 2002, 136, 310257.

5. (a) Benson, F. R.; Savell, W. L. Chem. Rev. 1950, 1. (b) Boyer, J. H. In Heterocyclic Compounds; Elderfield, R. C., Ed.; Wiley: New York, 1961; Vol. 7, Chapter 5, pp 384. (c) Gilchrist, T. L.; Gymer, G. E. In Advances in Heterocyclic Chemistry; Katritzky, A. R.; Boulton, A. J., Eds.; Academic Press: New York, 1974; Vol. 16, pp 33. (d) Lwowski, W. In 1,3-Dipolar Cycloaddition Chemistry; Padwa, A., Ed.; Wiley-Interscience: New York, 1984; Vol. 1, pp 559. (e) Sha, C.-K.; Mohanakrishnan, A. K. In The Chemistry of Heterocyclic Compounds; Padwa, A.; Pearson, W. H., Eds.; John Wiley: New York, 2002; Vol. 59, pp 623. (f) Rostovtsev, V. V.; Green, L. G.; Fokin, V. V.; Sharpless, K. B. Angew. Chem. Int. Ed. 2002, 41, 2596.

6. (a) Tamura, Y.; Chun, M. W.; Kwon, S.; Bayomi, S. M.; Okada, T.; Ikeda, M. Chem. Pharm. Bull. 1978, 26, 3515. (b) Abu-Orabi, S. T.; Atfah, M. A.; Jibril, I.; Mari'i, F. M.; Ali, A. A.-S. J. Heterocycl. Chem. 1989, 26, 1461. (c) Lalezari, I.; Gomez, L. A.; Khorshidi, M. J. Heterocycl. Chem. 1990, 27, 687. (d) Gouault, N.; Cupif, J.-F.; Sauleau, A.; David, M. Tetrahedron Lett. 2000, 41, 7293.

7. (a) Gorgues, A.; Le Coq, A. Tetrahedron Lett. 1979, 4829. (b) Banert, K. Chem. Ber. 1989, 122, 123. (c) Wigerinck, P.; Aerschot, A. V.; Claes, P.; Balzarini, J.; Clercq, E. D.; Herdewijn, P. J. Heterocycl. Chem. 1989, 26, 1635. (d) Buckle, D. R.; Rockell, C. J. M. J. Chem. Soc., Perkin Trans. 1 1982, 627. (e) Häbich, D.; Barth, W. Heterocycles 1989, 29, 2083. (f) Palacios, F.; Ochoa de Retana, A. M.; Pagalday, J. Heterocycles 1994, 38, 95. (g) Businelli, S.; Martino, D. E.; Zanirato, P. Arkivoc 2001, (i), 131.

8. Mearman, R. C.; Newall, C. E.; Tonge, A. P. J. Antibiot. 1984, 37, 885.

9. Makabe, O.; Suzuki, H.; Umezawa, S. Bull. Chem. Soc. Jpn. 1977, 50, 2689.

10. Olesen, P. H.; Nielsen, F. E.; Pedersen, E. B.; Becher, J. J. Heterocycl. Chem. 1984, 21, 1603.

11. (a) Ykman, P.; L’Abbe, G.; Smets, G. J. Indian Chem. Soc. 1972, 49, 1245; Chem. Abstr. 1973, 79, 19154. (b) Krongauz, E. S.; Korshak, V. V.; Travnikova, A. P. Vysokomol. Soedin., Ser. B 1967, 9, 563; Chem. Abstr. 1967, 67, 100460. (c) Yuldasheva, Kh.; Dzhuraev, A. D.; Makhsumov, A. G.; Amanov, N. Khim.-Farm. Zh. 1991, 25, 52; Chem. Abstr. 1992, 116, 18278. (d) Abu-Orabi, S.; Atfah, A.; Jibril, I.; Marii, F.; Ali, A. A.-S. Gazz. Chim. Ital. 1991, 121, 397; Chem. Abstr. 1992, 116, 21002. (e) Rogov, N. G.; Kabanova, E. P.; Gruzdeva, I. G. Ross. Khim. Zh. 1997, 41, 115; Chem. Abstr. 1997, 127, 206015.

12. Katritzky, A. R.; Zhang, Y.; Singh, S. K. Heterocycles 2003, 60, 1225.

13. (a) Crow, W. D.; Leonard, N. J. Tetrahedron Lett. 1964, 1477. (b) Crow, W. D.; Leonard, N. J. J. Org. Chem. 1965, 30, 2660. (c) Sasaki, T.; Eguchi, S.; Shoji, K. J. Chem. Soc. (C) 1969, 406. (d) Coppola, G. M.; Damon, R. E. Synth. Commun. 1993, 23, 2003. (e) Katritzky, A. R.; He, H.-Y.; Suzuki, K. J. Org. Chem. 2000, 65, 8210. 
14. (a) Sheradsky, T. In The Chemistry of the Azido Group; Patai, S., Ed.; Interscience: New York, 1971; Chapter 6, p 331. (b) Padwa, A. In Comprehensive Organic Synthesis; Trost, B. M.; Fleming, I., Eds.; Pergamon Press: New York, 1991; Vol. 4, p 1069.

15. Jungheim, L. N.; Sigmund, S. K. J. Org. Chem. 1987, 52, 4007.

16. (a) Hayes, B. L. Microwave Synthesis: Chemistry at the Speed of Light; CEM Publishing: Matthews, NC, 2002. (b) Lidström, P.; Tierney, J.; Wathey, B.; Westman, J. Tetrahedron 2001, 57, 9225. (c) Perreux, L.; Loupy, A. Tetrahedron 2001, 57, 9199. (d) Caddick, S. Tetrahedron 1995, 51, 10403. (e) de la Hoz, A.; Díaz-Ortis, A.; Moreno, A.; Langa, F. Eur. J. Org. Chem. 2000, 4, 3659. (f) Alterman, M.; Hallberg, A. J. Org. Chem. 2000, 65, 7984. (g) Varma, R. S. Green Chem. 1999, 1, 43. (h) Fini, A.; Breccia, A. Pure Appl. Chem. 1999, 71, 573. (i) Katritzky, A. R.; Singh, S. K. Arkivoc 2003, (xiii), 68.

17. Katritzky, A. R.; Singh, S. K. J. Org. Chem. 2002, 67, 9077.

18. Katritzky, A. R.; Lan, X.; Yang, J. Z.; Denisko, O. V. Chem. Rev. 1998, 98, 409.

19. (a) Rolla, F. J. Org. Chem. 1982, 47, 4327. (b) Abu-Orabi, S. T.; Harmon, R. E. J. Chem. Eng. Data 1986, 31, 379.

20. Theocharis, A. B.; Alexandrou, N. E.; Terzis, A. J. Heterocycl. Chem. 1990, 27, 1741.

21. Gabriele, B.; Salerno, G.; Veltri, L.; Costa, M. J. Organomet. Chem. 2001, 622, 84.

22. Sheldrick, G. M. Acta Crystallogr. Sect. A 1990, 46, 467.

23. Sheldrick G. M. SHELXTL; Bruker Analytical X-ray Systems, 1997. 